\title{
Heterogeneous Family of Cyclomodulins: Smart Weapons That Allow Bacteria to Hijack the Eukaryotic Cell Cycle and Promote Infections
}

\author{
Rachid A. El-Aouar Filho ${ }^{1,2 \dagger}$, Aurélie Nicolas ${ }^{1 \dagger}$, Thiago L. De Paula Castro ${ }^{2}$, \\ Martine Deplanche ${ }^{1}$, Vasco A. De Carvalho Azevedo ${ }^{2}$, Pierre L. Goossens ${ }^{3}$, \\ Frédéric Taieb ${ }^{4}$, Gerard Lina ${ }^{5,6,7}$, Yves Le Loir ${ }^{1}$ and Nadia Berkova ${ }^{1 *}$
}

${ }^{1}$ STLO, Agrocampus Ouest Rennes, Institut National de la Recherche Agronomique, Rennes, France, ${ }^{2}$ Departamento de Biologia Geral, Laboratório de Genética Celular e Molecular (LGCM), Instituto de Ciências Biológicas, Universidade Federal de Minas Gerais, Belo Horizonte, Brazil, ${ }^{3}$ HistoPathologie et Modèles Animaux/Pathogénie des Toxi-Infections Bactériennes, Institut Pasteur, Paris, France, ${ }^{4}$ CHU Purpan USC INRA 1360-CPTP, U1043 Institut National de la Santé et de la Recherche Médicale, Pathogénie Moléculaire et Cellulaire des Infections à Escherichia coli, Toulouse, France, ${ }^{5}$ International Center for Infectiology Research, Lyon, France, ${ }^{6}$ Centre National de la Recherche Scientifique, UMR5308, Institut National de la Santé et de la Recherche Médicale U1111, Ecole Normale Supérieure de Lyon, Université Lyon 1, Lyon, France, ${ }^{7}$ Département de Biologie, Institut des Agents Infectieux, Hospices Civils de Lyon, Lyon, France

OPEN ACCESS

Edited by:

Georgios N. Belibasakis, Karolinska Institutet, Sweden

Reviewed by:

Teresa Frisan,

Karolinska Institutet, Sweden

Guntram A. Grassl,

Hannover Medical School, Germany

*Correspondence:

Nadia Berkova

nadejda.berkova@inra.fr

${ }^{\dagger}$ These authors have contributed equally to this work

Received: 10 March 2017 Accepted: 09 May 2017

Published: 23 May 2017

Citation:

El-Aouar Filho RA, Nicolas A, De Paula Castro TL, Deplanche M, De Carvalho Azevedo VA, Goossens PL, Taieb F,

Lina G, Le Loir Y and Berkova N (2017) Heterogeneous Family of Cyclomodulins: Smart Weapons That Allow Bacteria to Hijack the Eukaryotic Cell Cycle and Promote Infections.

Front. Cell. Infect. Microbiol. 7:208. doi: 10.3389/fcimb.2017.00208
Some bacterial pathogens modulate signaling pathways of eukaryotic cells in order to subvert the host response for their own benefit, leading to successful colonization and invasion. Pathogenic bacteria produce multiple compounds that generate favorable conditions to their survival and growth during infection in eukaryotic hosts. Many bacterial toxins can alter the cell cycle progression of host cells, impairing essential cellular functions and impeding host cell division. This review summarizes current knowledge regarding cyclomodulins, a heterogeneous family of bacterial effectors that induce eukaryotic cell cycle alterations. We discuss the mechanisms of actions of cyclomodulins according to their biochemical properties, providing examples of various cyclomodulins such as cycle inhibiting factor, $\gamma$-glutamyltranspeptidase, cytolethal distending toxins, shiga toxin, subtilase toxin, anthrax toxin, cholera toxin, adenylate cyclase toxins, vacuolating cytotoxin, cytotoxic necrotizing factor, Panton-Valentine leukocidin, phenol soluble modulins, and mycolactone. Special attention is paid to the benefit provided by cyclomodulins to bacteria during colonization of the host.

Keywords: eukaryotic cell cycle alteration, bacterial toxins, cyclomodulins, colonization, invasion, infective efficiency, reduced host response

\section{BACTERIAL PATHOGENS HIJACK HOST DEFENSE RESPONSE}

Many pathogenic bacteria use sophisticated mechanisms to interfere with eukaryotic cells, to subvert the host response for their own benefit, and thus to colonize and invade the host tissues (Bhavsar et al., 2007; Alto and Orth, 2012). Bacterial pathogens can precisely target specific host cell activities such as cytoskeletal organization, cell cycle progression, vesicular trafficking and/or apoptosis using different effectors and delivery pathways (Zhou and Elledge, 2000). To 
do so, they produce substances, whose activity on the host cell results in an increased survival and replication and thus a better dissemination. These substances can manipulate pathways that regulate eukaryotic host cells (Alto and Orth, 2012). They can alter the host immune response, for example, by corrupting of MAP-signaling and NF- $\mathrm{B}$-pathway, major players of the immune response (Orth et al., 1999; Krachler et al., 2011; Lim and Staudt, 2013). Moreover, some bacterial virulence factors target evolutionarily conserved ubiquitylation machinery that regulates multiple cellular processes, including development, transcription, replication, cell signaling and immune function as shown in plant pathogens (e.g., Pseudomonas syringae pv. tomato) as well as animal or human pathogens (e.g., Escherichia coli or Citrobacter rodentium) (Huibregtse and Rohde, 2014). They can interact with eukaryotic modulating factors involved in the assembly of actin filaments, as was shown for the Rho GTPases-activating toxins such as the Cytotoxic Necrotizing Factor 1 described in E. coli (Bhavsar et al., 2007; Lemichez and Aktories, 2013). Their activity can ultimately hijack host response despite the negative pressure of the host immune system and induce a belated apoptosis of host cells bearing pathogens, which results in an extension of the time lapse for their replication.

To bypass the extracellular milieu and the membrane barrier, the bacterial effectors involved in such activities can be injected into the host eukaryotic cytoplasm, by specific injection systems such as Type III or Type IV Secretion Systems as demonstrated in Gram negative pathogens like enteric Escherichia coli, Salmonella, Yersinia, and Shigella (T3SS) or in Brucella sp. (T4SS) (Ashida et al., 2012). In contrast, toxins referred to as $A B$ toxins, where " $A$ " is the subunit with enzymatic activity and " $B$ " is the subunit binding receptors on the cell surface, are rather internalized through endocytosis (Odumosu et al., 2010).

Despite the importance of such findings, until recently, not much attention was paid to the investigation of the capacity of bacteria to alter the host cell cycle and to the analysis of this alteration on the outcome of the infection.

\section{THE CELL CYCLE OF EUKARYOTIC CELLS AND CELL CYCLE REGULATION}

The eukaryotic cell cycle is a ubiquitous and complex process involving DNA replication, chromosome segregation and cell division. The cell cycle consists of different phases: the gap phase 1 (G1), characterized by cell growth; the S-phase characterized by DNA replication; the gap phase 2 (G2), in which cells are prepared for division; and the mitosis (M) phase, which culminates in cell division. Cells can also exit the cell cycle and enter a quiescent state, the G0 phase (Figure 1; Vermeulen et al., 2003).

Cell cycle progression is controlled by the activities of complexes that consist of cyclins (A, B, D, E) bound to cyclindependent protein kinases (CDKs). The D-type cyclins activate the CDK4 and CDK6, which are required for an entry and a progression of cells into the G1-phase. To progress from the G1 to the $\mathrm{S}$ phase, cyclin E associates with CDK2. Cyclin A associated with CDK2 allows progression through the $S$ phase. In the G2

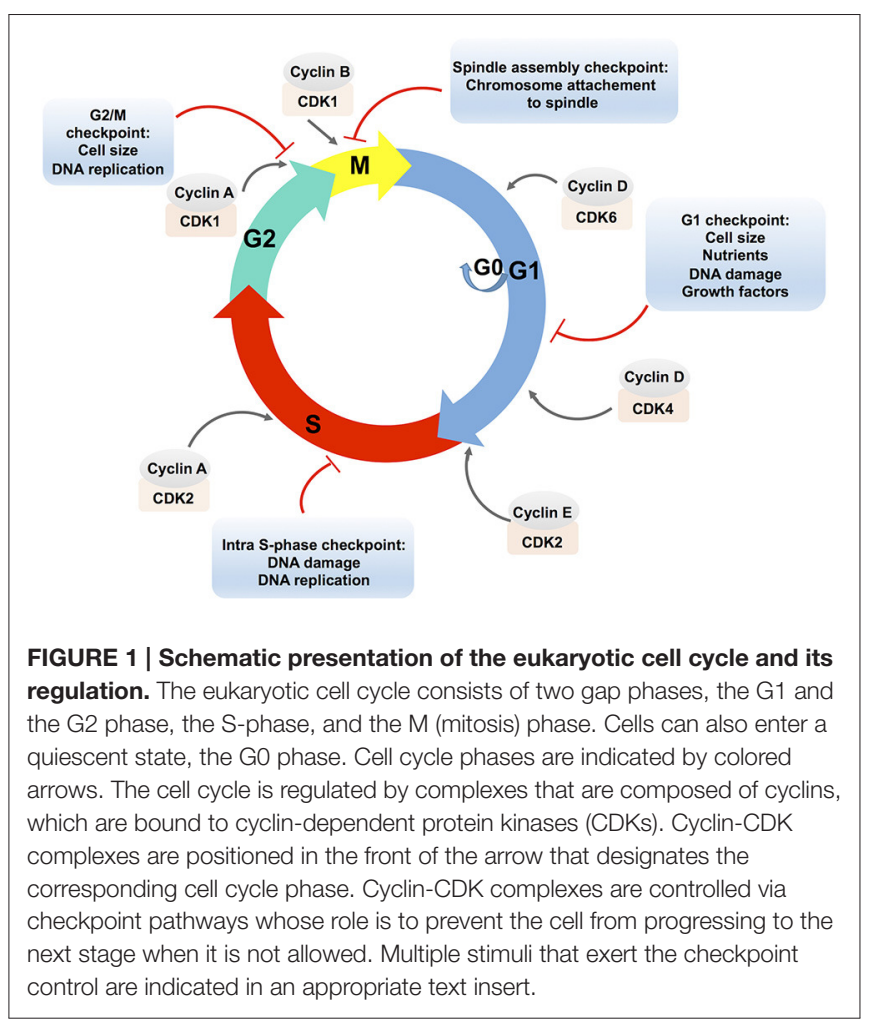

phase, cyclin A associated with CDK1 triggers the entry into the $M$ phase. Subsequently, cyclin B activates the CDK1 and promotes the M phase of the cell cycle (Lim and Kaldis, 2013).

The formation and activity of cyclin-CDK complexes are regulated by the synthesis of cyclins and their degradation during the cell cycle progression, by the CDK phosphorylation status, or by the binding of CDK inhibitory proteins to the cyclin-CDK complexes (Lim and Kaldis, 2013).

The combined effects of these pathways control the cell cycle progression in response to external stimuli as well as to the internal cell environments, e.g., through the checkpoint pathways. In addition to the modulation of the cell cycle, checkpoint pathways control DNA repair pathways, activation of transcriptional programs, and stimulation of apoptosis in case of persistent damage (Zhou and Elledge, 2000). Checkpoint arrests occur at different stages of the cell cycle: the G1/S transition (the G1 checkpoint), the S phase progression (the intra-S phase checkpoint), the G2/M boundary (the G2/M checkpoint) and the spindle checkpoint at the transition from metaphase to anaphase during mitosis (Figure 1). Checkpoint activation results either in cell death or in improved cell survival and deregulation of these critical signaling pathways may lead to the disruption of essential cellular functions. It has to be noted that the expression of many genes is cell cycle-regulated (Grant et al., 2013) and it was shown that transcriptional and post-transcriptional mechanisms control cell cycle regulators (Nath et al., 2015).

In some cases, bacterial pathogens have developed strategies to promote their colonization, with the action of virulence factors controlling the main host functions, including cell 
cycle. This review is designed to summarize current knowledge regarding cyclomodulins, bacterial toxins and effectors that induce eukaryotic cell cycle alterations (Nougayrede et al., 2005; Oswald et al., 2005). The role of bacterial cyclomodulins in the context of the host-microbes interaction is the emergent issue in the field of infectious diseases. While the structures and the mechanisms of the action of cyclomodulins are regularly investigated, the data regarding the analysis of the cell cycle alteration on the outcome of the infection is very scarce. We discussed bacterial virulence factors for which the consequence of their cyclomodulin activities has been described. Representative cyclomodulins with the different modes of actions are provided in the review. Particular attention is paid to the deciphering of the consequences of host cell cycle alteration.

\section{BACTERIAL CYCLOMODULINS}

Bacteria produce virulence factors including effectors injected by bacteria into the host cells and toxins released by bacteria into the surrounding medium, which hijack the main functions of host cells thus promoting bacterial invasion and host colonization. Growing evidence demonstrates that the host cell cycle progression is one of the most favorable targets of these virulence factors. Therefore, a new classification of bacterial toxins and effectors, based on their ability to alter the host cell cycle, has emerged under the term cyclomodulin (Nougayrede et al., 2005; Oswald et al., 2005). Our understanding of the capacities of cyclomodulins to alter the eukaryotic cell cycle roughly follows the investigations of their structure and the deciphering of their mechanisms of action (Ha et al., 2007; Li et al., 2007; Deplanche et al., 2015). The cyclomodulins are a heterogeneous functional class of microbial virulence factors: most cyclomodulins consist of proteins, but the existence of nonproteinaceous bacterial cyclomodulin with different mechanisms of action was also reported. Some of the cyclomodulins have enzymatic activities and they are classified as transferase, deamidase, deaminase, protease, glycosidase, phosphatase or DNAses. Among cyclomodulins, which display enzymatic activities there are $\mathrm{AB}$ toxins, that interact with receptors on the cell surface using one or several B-binding domains and modify the action of intracellular host targets through their enzymatic activities via A-active domain (Odumosu et al., 2010).

In addition to the cyclomodulins bearing an enzymatic activity, there are pore-forming proteinaceous cyclomodulins (e.g., PVL), peptidic cyclomodulins (e.g., PSM), as well as nonproteinaceous ones (e.g., mycolactones).

Cyclomodulins thus belong to a growing and heterogeneous family and we can expect that other bacterial molecules will enrich this family.

Up to date, there is no precise classification of bacterial cyclomodulins. We therefore proposed hereafter a presentation order based on the proteinaceous or non-proteinaceous nature of the cyclomodulins. Among proteinaceous cyclomodulins, we distinguish those bearing an enzymatic activity and the nonenzymatic ones.

\section{Cyclomodulins: Protein Toxins or Peptide Toxins Cyclomodulins with Enzymatic Activities Cycle inhibiting factor}

Enterohemorrhagic and enteropathogenic E. coli strains (EHEC and EPEC, respectively) are major causes of infectious diarrhea in children worldwide. EHEC and EPEC use the Type III secretion system (T3SS) encoded by the Locus of Enterocyte Effacement (LEE) to promote their establishment within the host by delivering different virulence effectors to infected host cells (Table 1; Hsu et al., 2008). Cycle inhibiting factors (CIFs) are effectors delivered by EHEC and EPEC through T3SS. CIF is not encoded by the LEE but instead by a lambdoid prophage that has possibly been acquired through horizontal transfer (Hsu et al., 2008). CIF causes cell arrest at both the G1/S and G2/M transitions by accumulation of the CDK inhibitors, p21 ${ }^{\text {Cip1 }}$ and p27 ${ }^{\text {Kip1 }}$ (Samba-Louaka et al., 2008; Morikawa et al., 2010; Taieb et al., 2011). Such arrest is mediated by deamidation of the ubiquitin-like protein NEDD8 by CIF (Cui et al., 2010) demonstrating that CIF displays deamidase enzymatic activity. NEDD8 deamidation impairs the conjugation of NEDD8 to Cullin, which inactivates a Cullin-Ring ubiquitin Ligase (CRL) (Cui et al., 2010). The inactivation of CRLs results in inhibition of the ubiquitin-dependent degradation pathway and thus accumulation of CRLs' substrates, including p21 Cip1 and $227^{\mathrm{Kipl}}$ which induces the host cell cycle arrest (Zhou and Zhu, 2015). Cells exposed to CIF have also shown formation of stress fibers and focal adhesion (Samba-Louaka et al., 2009b) beyond the cellular and nuclear enlargement that probably result from inhibition of CRL-dependent RhoA degradation (Chen et al., 2009; Jubelin et al., 2010). In such cases, cells may restart the DNA synthesis process without proceeding to division, probably owing to the inhibition of CRL dependent degradation of the licensing factor Cdt1, thus increasing their DNA content (Nougayrede et al., 2001; Jubelin et al., 2010). Proteins homologous to CIF proteins were found in several other pathogenic Gram negative species or genera (Yersinia pseudotuberculosis, Photorhabdus luminescens, Photorhabdus asymbiotica, and Burkholderia pseudomallei) (Jubelin et al., 2009). Consistent with the fact that CIF proteins are T3 secreted effector, all these bacteria possess a T3SS. Despite the differences in primary sequences of these homologs, the catalytic site is conserved and was demonstrated to play a pivotal role in the eukaryotic cell cycle alteration and the cytoskeleton reorganization (Jubelin et al., 2009).

\section{$\gamma$-glutamyltranspeptidase}

Helicobacter pylori is a Gram-negative bacterium that colonizes the intestinal mucosa and causes several diseases such as chronic gastritis, gastric cancer and ulcers. H. pylori produces a hydrolase $\gamma$-glutamyltranspeptidase, (GGT), a virulence factor that catalyzes the transpeptidation and hydrolysis of the gammaglutamyl group of glutathione and related compounds (Table 1; Ricci et al., 2014).

H. pylori GGT is synthesized as a single $60 \mathrm{kDa}$ precursor protein expressed by the gene HP1118 (Shibayama et al., 2003). 
TABLE 1 | Cyclomodulins and their key features.

\section{Toxin type}

Species

Proteins

Enzymatic activity

Cell cycle

phase delay

\section{PROTEIN OR PEPTIDES TOXINS}

Cyclomodulins with enzymatic activities

Cycle Inhibiting Cysteine protease

Factor (CIF)

E. coli (EHEC, EPEC)

2 domains: $N$-terminal (secretion Deamidase

G1/S and translocation)

Y. pseudotuberculosis

Pseudomonas sp.

Enterobacter sp.

Serratia sp.

\begin{tabular}{|c|c|c|c|c|c|}
\hline $\begin{array}{l}\Gamma \text {-glutamyl } \\
\text { transpeptidase } \\
(\text { GGT) }\end{array}$ & Enzyme & H. pylori & $\begin{array}{l}1 \text { protein with } 2 \text { chains cleaved } \\
\text { by autocatalysis }\end{array}$ & Gamma-glutamyltransferase & G1/S \\
\hline $\begin{array}{l}\text { Subtilase AB } \\
\text { (SubAB) }\end{array}$ & AB5 toxin & E. coli (STEC) & $\begin{array}{l}\text { SubA enzymatic subunit SubB } \\
\text { binding subunit }\end{array}$ & A subunit: protease & G1/S \\
\hline $\begin{array}{l}\text { Anthrax toxin } \\
\text { (Edema toxin/Lethal } \\
\text { toxin) }\end{array}$ & Tripartite toxin & B. anthracis & $\begin{array}{l}\text { Edema and/or Lethal factor (A } \\
\text { enzymatic subunit) Protective } \\
\text { Antigen ( } B \text { binding subunit) }\end{array}$ & $\begin{array}{l}\text { Edema factor : adenylate cyclase } \\
\text { Lethal factor: zinc } \\
\text { metalloprotease }\end{array}$ & $\mathrm{G} 1 / \mathrm{S}$ \\
\hline $\begin{array}{l}\text { Adenylate Cyclase } \\
\text { Toxin (ACT) }\end{array}$ & AB5 toxin & B. pertussis & $\begin{array}{l}\text { S1 enzymatic A subunit S2 to S5 } \\
\text { binding B subunits }\end{array}$ & A subunit: acetyltransferase & G1/S \\
\hline $\begin{array}{l}\text { Vacuolating } \\
\text { cytotoxin (VacA) }\end{array}$ & Pore-forming toxin & H. pylori & 3 domains (p33, p55, $\beta$-barrel) & Hypothetically & G1/S \\
\hline $\begin{array}{l}\text { Cytotoxic } \\
\text { Necrotizing Factor } 1 \\
\text { (CNF1) }\end{array}$ & Non canonical AB toxin & E. coli & $\begin{array}{l}3 \text { domains: N-terminal (binding) } \\
\text { C-terminal (enzymatic) Central } \\
\text { (translocation) }\end{array}$ & Deaminase & G2/M \\
\hline \multicolumn{6}{|c|}{ Cyclomodulins without enzymatic activities } \\
\hline
\end{tabular}

Following an autocleavage at Threonin 380, GGT releases two units, $40 \mathrm{kDa}$, and $20 \mathrm{kDa}$, which form the active heterodimer (Shibayama et al., 2003). The enzymatic activity of GGT resides in the $20 \mathrm{kDa}$ subunit with the gamma-glutamyl binding site at the Tyr433, and the Arg475 residues and the C-terminus of $20 \mathrm{kDa}$ subunit contributes to catalysis (Williams et al., 2009).
GGT, as a virulence factor, has gained increased attention during the past decade due to its harmful effects on the host. GGT is mainly associated with colonization and gastric ulcer induction, as was observed in some animal models (McGovern et al., 2001; Gong et al., 2010). GGT causes damage to gastric cells, including apoptosis (Shibayama et al., 2003), the production of reactive oxygen species causing DNA damage (Ding et al., 
2007; Gong et al., 2010), an induction of inflammatory responses by an increase in the expression of cyclooxygenase-2 (Busiello et al., 2004) and interleukin 8 (Gong et al., 2010), as well as cell cycle delay (Kim et al., 2010). Exposure of human cancer cells AGS (gastric adenocarcinoma cells) to GGT resulted in G1 phase arrest. The arrest was associated with a decrease in the expression of cyclin E, cyclin A, Cdk 4, and Cdk 6, and with an increase in the expression of the cyclin-dependent kinase (Cdk) inhibitors $\mathrm{p} 27^{\mathrm{Kip} 1}$ and $\mathrm{p} 21^{\mathrm{Cip} 1}$, suggesting that GGT hampers the G1-S phase transition (Kim et al., 2010). Recently it was shown that additionally to the G1 phase arrest in epithelial cells $H$. pylori GGT induces the G1 phase arrest of T cells through the disruption of Ras-dependent signaling (Schmees et al., 2007).

\section{Cytolethal distending toxin}

Cytholetal distending toxin (CDT) is produced by a variety of Gram-negative bacteria such as E. coli, Helicobacter hepaticus, Actinobacillus actinomycetemcomitans and other bacteria (DiRienzo, 2014; Taieb et al., 2016; Table 1). Initially CDT, a member of $\mathrm{AB}_{2}$ toxin superfamily, was described in 1987 in a pathogenic E. coli strain isolated from a child (Anderson et al., 1987). CDT blocks the cell cycle of the host cell and induces DNA single and double strand breaks (DSB). It may induce an increased risk of cancer development (Anderson et al., 1987; Ge et al., 2007; Grasso and Frisan, 2015).

$\mathrm{CDT}$ is the product of an operon encoding three proteins: $\mathrm{CdtA}, \mathrm{CdtB}$, and CdtC. CDT is an $\mathrm{AB}_{2}$ type toxin in which the $\mathrm{CdtB}$ subunit corresponds to the $\mathrm{A}$ (active)-domain and exhibits a DNase activity responsible for DSB, and a phosphatase activity that resembles that of phosphatidylinositol 3,4,5-triphosphatase (Elwell and Dreyfus, 2000; Shenker et al., 2007; Guerra et al., 2011; Gargi et al., 2012; Grasso and Frisan, 2015). CdtA and $\mathrm{CdtC}$, are two ricin-like lectin domains, which allow CDT to bind to the susceptible cell ( $\mathrm{B}_{2}$-domain), leading to its internalization. $\mathrm{CdtB}$ is then relocated to the nucleus by a retrograde transport pathway via early and late endosomes (Guerra et al., 2005). It was shown that $\mathrm{CdtA}, \mathrm{CdtB}$, and $\mathrm{CdtC}$ form a ternary complex with three interdependent molecular interfaces (Nesić et al., 2004).

In contrast to other pathogens, in the Salmonella typhi typhoid toxin, an $\mathrm{A}_{2} \mathrm{~B}_{5}$ toxin, $\mathrm{CdtB}$ is cross-linked via a disulfide bond to PltA (the pertussis-like toxin $\mathrm{A}$, homologous to the pertussis toxin ADP-ribosyltransferase subunit). These two active (A) proteins are non-covalently bound with a $\mathrm{B}_{5}$ (binding) subunit consisting of a pentameric PltB (pertussis-like toxin B) subunit responsible for cell binding instead of being associated with CdtA and CdtC (Spanó et al., 2008; Song et al., 2013; Bezine et al., 2014).

The CdtB subunit is highly conserved among various bacteria and has $25-40 \%$ identity with phosphodiesterase enzymes, including DNase I (Elwell and Dreyfus, 2000; Nesić et al., 2004). The nuclease activity shown by this subunit triggers a DNA damage response (DDR) (Grasso and Frisan, 2015). The activation of the DDR is initiated by the ataxia telangiectasia mutated (ATM) kinase that phosphorylates CHK2, a serine/threonine kinase that, in turn, phosphorylates various cell cycle regulators such as phosphatases Cdc25A and Cdc25C (Figure 2; Bezine et al., 2014). Phosphorylation of Cdc25C creates an interaction site for the 14-3-3 family of proteins that sequester Cdc25C in the cytoplasm (Ahn et al., 2004). Thus, phosphatase $\mathrm{Cdc} 25 \mathrm{C}$ is unable to activate the nuclear hyperphosphorylated (inactive) CDK1/cyclin B complex, leading to the delay in the G2/M phase transition of the cell cycle (Taieb et al., 2015). Delay at the G1/S phase by CDT is also reported, and results from an ATM/p53-dependent accumulation of the CDK2cyclin $\mathrm{E}$ inhibitor, $\mathrm{p} 21^{\mathrm{Cip} 1}$. Inhibition of CDK2-cyclin $\mathrm{E}$ blocks the entry into the $\mathrm{S}$ phase of the cell cycle (Cortes-Bratti et al., 2001; Ge et al., 2008).

Evidence indicates that CDT is a beneficial virulence factor for bacterial survival (Scuron et al., 2016). It was found that CDT increases bacterial gut colonization, promotes proinflammatory responses, and deregulates immune response

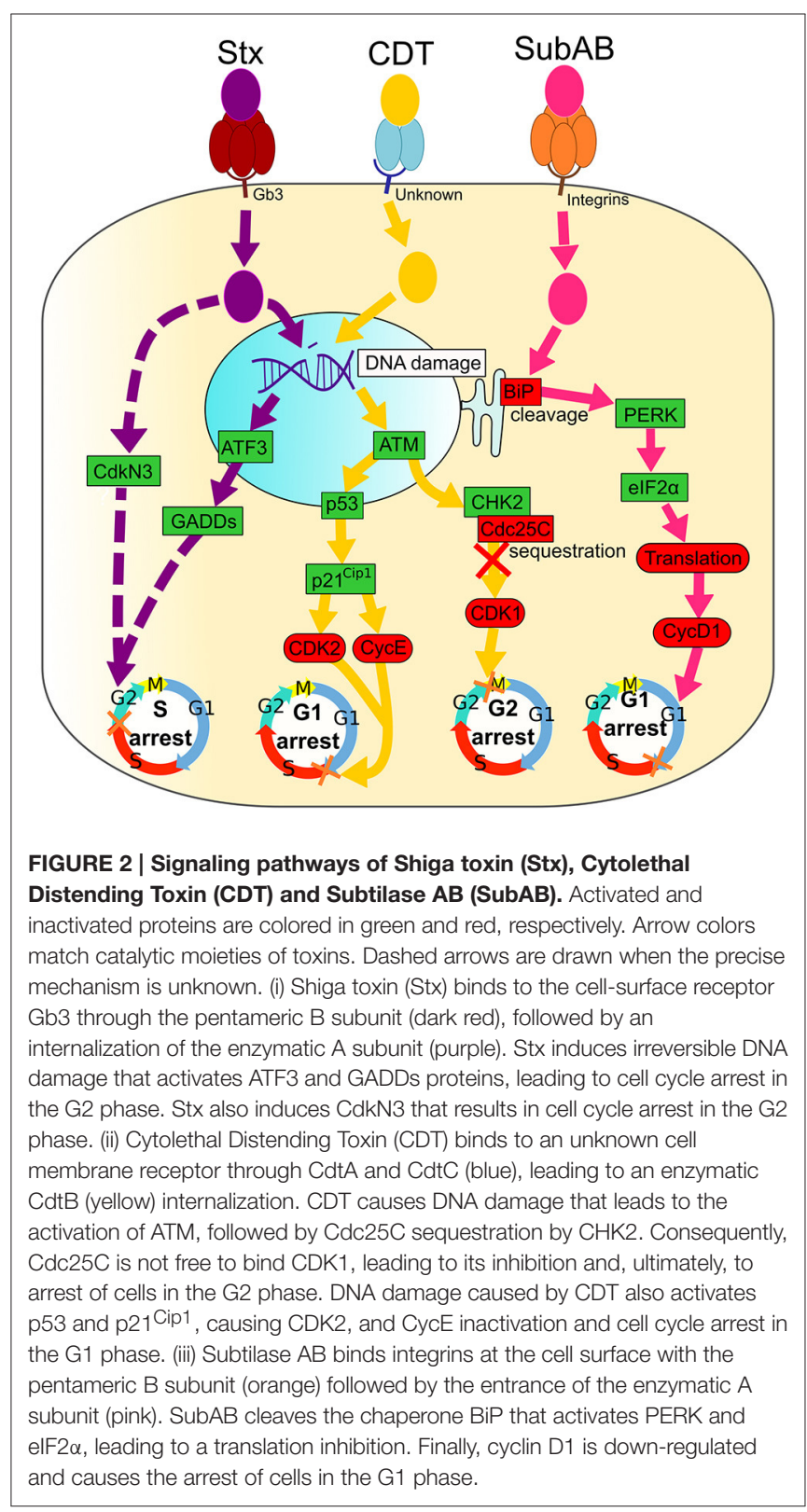


through an alteration of cytokine synthesis that may in turn increase the local inflammation (Akifusa et al., 2001; Ge et al., 2008; Jain et al., 2008; Belibasakis and Bostanci, 2014). Moreover, it was shown that CDT of A. actinomycetemcomitans interferes with bone metabolism notably by affecting the signaling of osteoclast differentiation at the site of the infection (Belibasakis et al., 2005a,b, 2008).

The effect caused by CDT may lead to apoptosis or necrosis of cells through the mitochondrial effectors Bax/Bcl-2, cytochrome $\mathrm{C}$ release and caspase activation (Liyanage et al., 2010). The consequence of the genotoxic effects of CDT is related to the induction of cellular senescence associated with persistently activated DNA damage signaling that may result in genomic instability (Bezine et al., 2014; Graillot et al., 2016).

Colibactin is another well-known cyclomodulin produced by E. coli and as the CDT genotoxin, induces host DNA strand breaks and activates the DNA damage response. The mode of action of colibactin has been previously described in numerous publications (Balskus, 2015; Rosadi et al., 2016; Taieb et al., 2016).

\section{Shiga toxin}

Shiga toxins (Stxs) are produced by Shigella dysenteriae serotype 1 bacteria and E. coli, capable of producing Shiga toxin type 1 (Stx1), type 2 (Stx2), or both, encoded by stx 1 and $s t x 2$ genes, respectively (Table 1; Paton and Paton, 1998; Johannes and Romer, 2010). Cytotoxin from culture filtrates of some diarrheainducing E. coli strains similar to Shiga toxin was able to kill Vero cells, consequently this toxin was also named verotoxin. These Shiga toxin-producing E. coli (STEC) or Verotoxin-producing E. coli (VTEC) produce the same toxin, known as Shiga toxin or Verotoxin (Lee et al., 2016). S. dysenteriae and STEC are major public health concerns in developed and developing countries since they can induce hemorrhagic colitis or hemolytic-uremic syndrome (Farrokh et al., 2013). Stx belongs to the family of $\mathrm{AB}_{5}$ toxins that consist of the ribosomal $32 \mathrm{kDa}$ RNA-cleaving $\mathrm{A}$ subunit, which is non-covalently bound to five receptor-binding 7.7 kDa B subunits (Figure 2; Melton-Celsa, 2014). Once bound to the host cells receptor (Gb3), the toxins are internalized and undergo retrograde intracellular trafficking: they are transported from an early endosome, through the Golgi apparatus, to the endoplasmic reticulum (ER) (Sandvig et al., 2010). During this retrotranslocation, the A subunit dissociates from the B subunit due to a proteolysis and a disulfide bond reduction (MeltonCelsa, 2014). Once in the cytoplasm, the A subunit acquires a native conformation and activates its enzymatic features, leading to the removal of an adenine residue from the ribosomal RNA of eukaryotic cells and, subsequently, to an impaired protein synthesis (Melton-Celsa, 2014).

In addition to the protein synthesis inhibition, Stx induces the ribotoxic stress response and ER stress that may result in apoptosis, autophagy or an activation of the innate immunity associated with a cytokine/chemokine production that contribute to tissue damage in multiple organs (Jandhyala et al., 2008; Lee et al., 2016). It was shown that Stx induces an arrest of epithelial cells in the $S$ phase of a cell cycle (Figure 2), which is a consequence of irreversible DNA damage (Bhattacharjee et al., 2005). The delay in the $S$ phase is associated with an upregulation of genotoxic stress response genes both at mRNA and protein levels. The level of the ATF3 (Activating Transcription Factor), three GADD (Growth Arrest and DNA Damage) family genes (GADD45a, GADD45b, and GADD34), and the cell cyclerelated phosphatase CdkN3 (Bhattacharjee et al., 2005), which is an inhibitor of CDKs (Nalepa et al., 2013) is increased in Stxs-treated cells.

\section{Subtilase toxin}

Subtilase toxin (SubAB) is an $\mathrm{AB}_{5}$ type toxin that is produced by STEC (Table 1; Paton and Paton, 2010). The in vivo effects of SubAB have been examined in mice and were shown to cause microvascular injury, thrombosis and necrosis in various organs such as the brain, the liver and the kidneys (Paton et al., 2004). SubAB may contribute to the pathogenesis of a systemic hemolytic uremic syndrome.

Similar to other AB toxins, five $13 \mathrm{kDa} B$ subunits of SubAB bind to the host cells receptors, while the $35 \mathrm{kDa}$ A subunit possesses an enzymatic activity that is essential for cytotoxicity (Michelacci et al., 2013). Once internalized into the cells by endocytosis, SubAB trafficks through Golgi to the ER (Morinaga et al., 2008). SubAB induces ER stress and cleaves the chaperone $\mathrm{BiP} / \mathrm{Grp} 78$ in its carboxy-terminal portion, localized in lumen of ER. BiP/Grp78 is essential for the proper folding and the assembly of nascent proteins (Figure 2; Nours et al., 2013). This results in the inhibition of protein synthesis (Morinaga et al., 2008). SubAB-induced ER stress caused many other cellular events such as transient phosphorylation of Akt and activation of NF- $\kappa B$ signaling, a down-regulation of gap junction expression and an induction of apoptosis (Yahiro et al., 2014).

The cleavage of BiP/Grp78 was associated with a phosphorylation of a double-stranded RNA-activated protein kinase-like ER kinase (PERK) and a eukaryotic initiation factor$2 \alpha$ (eIF2 $\alpha$ ) (Morinaga et al., 2008). A degradation of BiP/Grp78 leads to cyclin D1 down-regulation caused by both a SubABinduced translational inhibition and a continuous proteasomal degradation, and results in G1 phase arrest (Figure 2; Morinaga et al., 2008; Yahiro et al., 2012; Márquez et al., 2014).

\section{Anthrax toxin}

Bacillus anthracis is the causative agent of anthrax, a disease with local or systemic clinical manifestations. Cutaneous anthrax is characterized by edematous necrotic lesions that become black eschars, while systemic anthrax has a multiplicity of symptoms, including of hypotension and shock, followed by sudden death (Ascenzi et al., 2002).

The $B$. anthracis toxins are in fact a tripartite toxin, which belongs to the $\mathrm{AB}$ toxin family. It consists of the heptameric protective antigen (PA) (B subunits) and two alternative A subunits: the lethal factor (LF), forming lethal toxin (LT), and the edema factor (EF), forming edema toxin (ET) (Table 1; Friebe et al., 2016).

Using in vivo mice model it was shown that subcutaneous administration of ET results in skin edema, while intravenously injected ET can directly target intestinal epithelial cells and hepatocytes and has been shown to be lethal through its action 
in hepatocytes (Moayeri et al., 2015). The $83 \mathrm{kDa}$ PA binds to protein receptors on the host cells, such as tumor endothelial marker 8 (TEM8), also known as anthrax toxin receptor 1 and capillary morphogenesis gene product 2 (CMG2), also known as anthrax toxin receptor 2, followed by the entrance of the catalytic moieties of the toxins, EF or LF, into the host cell cytoplasm (Bradley et al., 2001; Scobie et al., 2003). EF is an adenylate cyclase that, upon translocation into host cells and after association with the calcium-binding protein, calmodulin, catalyzes the production of a ubiquitous second messenger cyclic AMP (cAMP), resulting in the impairment of the cell homeostasis through multiple changes (Figure 3; Leppla, 1982; Tang and Guo, 2009).

The proliferation of many cells is controlled by the phosphorylation of extracellular signal-regulated kinase ERK due to the action of mitogen-activated protein kinase (MEK) that communicates a signal from cellular receptors to the nuclear DNA, thereby regulating the gene expression; this transduction pathway is influenced by cAMP (New and Wong, 2007). EF-induced cAMP production reduces the amount of the phosphorylated ERK and stimulates phosphorylation of the Cyclic AMP Response-Element Binding (CREB) protein in part through cAMP-dependent Protein Kinase A (PKA) (Gray and Hewlett, 2011). EF-induced cAMP accumulation leads to a decrease in the level of cyclin D1 that, together with CDKs, regulates the entry into the G1 phase. The level of $\mathrm{p} 27^{\mathrm{Kip} 1}$, which inhibits the complex of cyclin D and CDKs, is augmented due to the cAMP increase. Consequently, an accumulation of cells in the G1/G0 phase and a decrease of cells in the S phase occurs in ET-treated cells (Gray and Hewlett, 2011).

LF, the other catalytic subunit of the anthrax toxin, is a zinc metalloprotease that cleaves and inactivates the N-terminal end of MEKs. It leads to the inhibition of ERK, followed by a down-regulation of cyclin D1, cyclin D2 and checkpoint kinase 1 (Ha et al., 2007). The important role of cyclin D1 and D2 for escaping from G1 and initiation and completion of S phase through activating cyclin-dependent kinases 2, 4, and 6 has been documented (Sanchez and Dynlacht, 2005). Those events result in the arrest of cells in the G1/G0 phase of the cell cycle (Figure 3; Ha et al., 2007). Ultimately an LF-induced cleavage of MEK, which would lead to impairment of cyclin function and homeostasis, promotes a belated induction of cell death via a transcriptome deregulation of host factors, resulting in its cytotoxicity on human endothelial cells (Rolando et al., 2010).

\section{Cholera toxin}

The cholera toxin (CT or CTX) is the major virulence factor of Vibrio cholera and the main diarrhea-causing enterotoxin (Table 1). CTX is a member of the $\mathrm{AB}_{5}$ toxin family that consist of a cell surface receptor-binding homopentameric $B$ subunit (CTB) that is linked to a catalytic A subunit (CTA). CTA comprises the CTA1 domain, which activates $G$ proteins and CTA2 domain (Figure 3; Sánchez and Holmgren, 2011). The pentameric CTB subunit binds to GM1 gangliosides receptors of target cells or to other types of glycans. A binding of the pentameric CTB subunit to the GM1 ganglioside receptor on the intestinal cells (enterocytes) triggers CTX endocytosis followed

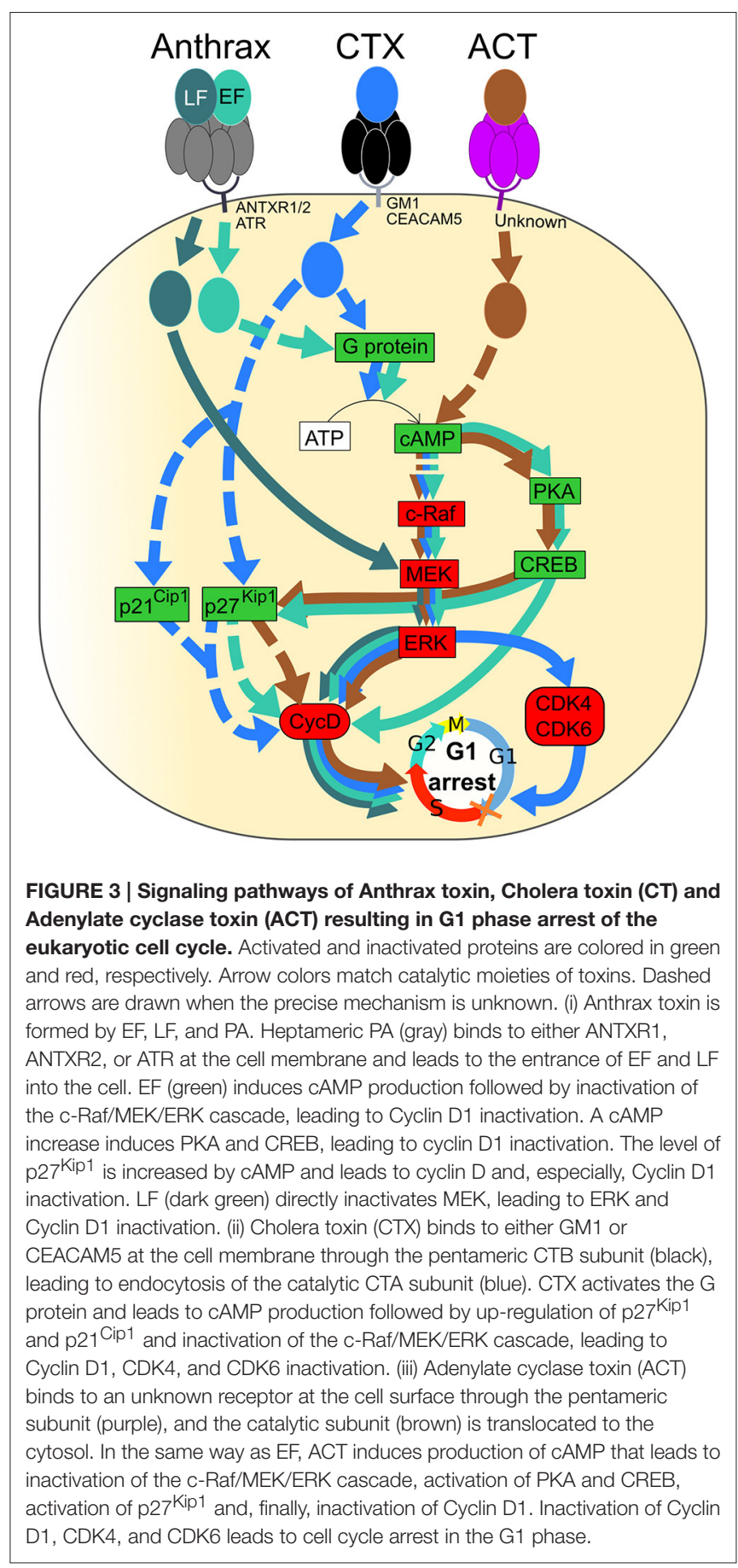

by the cleavage of CTA1, which then becomes an active enzyme. Once activated, CTA1 catalyses ADP-ribosylation of the Gs alpha subunit $\left(G \alpha_{s}\right)$ of the $G$ protein, thereby stimulating adenylate cyclase to produce cAMP (Figure 3). The high cAMP levels impede the electrolyte balance, causing a drastic efflux of ions and water from enterocytes, leading to watery diarrhea (Nichols et al., 2015).

CTX induces the G1-phase arrest in eukaryotic cells. The capacity of CTX to modulate the cell cycle progression of C6 
rat glioma cells was reported by Li et al. (2007). CTX induces an accumulation of cells in the G1 phase due to the downregulation of cyclin D1 and CDK2 proteins along with an up-regulation of the cell-cycle inhibitory proteins, $\mathrm{p} 21^{\mathrm{Cip} 1}$ and p27 ${ }^{\text {Kip1 }}$ (Figure 3; Li et al., 2007). Moreover, using two human bladder cell lines, T24 and UM-UC-3, it was demonstrated that CTX inactivates the c-Raf/Mek/Erk cascade, via the PKAdependent c-Raf phosphorylation at Ser-43. This results in the downregulation of the expression of the regulatory molecules (cyclin D1, Cdk4, and Cdk6), followed by the G1 phase arrest (Figure 3; Zheng et al., 2014).

\section{Adenylate cyclase toxin}

Bordetella pertussis, a Gram-negative bacterial pathogen, is responsible for respiratory infections manifested by whooping cough, with possible lethal complications (Table 1). Similar to $B$. anthracis, $B$. pertussis produces an adenylate cyclase toxin (ACT), which belongs to the $\mathrm{AB}_{5}$ toxin family (Figure 3; Melvin et al., 2014). ACT of B. pertussis is a $\sim 200 \mathrm{kDa}$ protein consisting of two functional domains: an $\mathrm{N}$ - terminal adenylate cyclase enzyme domain (AC domain) and a pore-forming or hemolysin domain (Hly domain), which belongs to the RTX (Repeats in Toxin) family (Carbonetti, 2010). ACT displays the hemolytic/pore-forming activity along with the adenylate cyclase enzymatic activity (Basler et al., 2006). ACT is released by the Type I bacterial secretion system (Glaser et al., 1988). The Hly domain is required for the delivery of the AC domain into the cell cytosol either via binding to the $\alpha_{\mathrm{m}} \beta_{2}$ integrin $(\mathrm{CD} 11 \mathrm{~b} / \mathrm{CD} 18)$ as a cell receptor or by direct translocation to the eukaryotic cells cytosol (Guermonprez et al., 2001; Eby et al., 2010).

Once reaching the cytosol, the AC domain is activated through binding of calmodulin (the mammalian cytosolic protein) and it catalyses the conversion of intracellular ATP into cAMP, the key second messenger signaling molecule (Basler et al., 2006; Kamanova et al., 2008).

It was reported that the ACT-induced cAMP signaling and ATP depletion together with pore-forming activity, can synergize in promoting of apoptosis or necrosis of phagocytes (Khelef and Guiso, 1995; Bachelet et al., 2002). An analysis of the effects of $B$. pertussis on the regulatory pathways controlling the cell cycle reveals that ACT stimulates PKA, which activates CREB through its phosphorylation that, in turn, decreases the Cyclin D level, followed by G1 phase arrest (Gray and Hewlett, 2011). On the other hand, B. pertussis ACT-induced cAMP via the c-Raf-MEK complex may inhibit ERK phosphorylation, resulting in decrease of the Cyclin D level and, consequently, causing a block in cell cycle progression at the G1-S transition (Gray and Hewlett, 2011; Figure 3). Furthermore, ACT may increase the cyclin-dependent kinase inhibitor, p27Kip1. Such a regulatory profile causes an accumulation of infected cells in the G1/G0 phase and a reduction of cells in the S phase (Gray and Hewlett, 2011; Figure 3).

\section{Vacuolating cytotoxin}

One of the major virulence factors reported for $H$. pylori is vacuolating cytotoxin A ( VacA), which is known for its ability to induce the formation of large acid vesicles in the cytoplasm of gastric cells (Table 1; Cover and Blaser, 1992; Palframan et al., 2012). Cytoplasmic vacuolation is caused by the osmotic swelling of late endocytic compartments related to a VacA-dependent increase in anionic permeability. The formation of anionconducting channels in intracellular membrane can help $H$. pylori colonization by allowing the efflux of metabolic substrates, which provides a selective advantage to toxin-producing strains in the nutrient-poor environment of the gastric mucous layer (Mendz et al., 1994).

VacA is synthesized as a $140 \mathrm{kDa}$ pre-protoxin, which undergoes proteolytic processing during secretion, resulting in a mature $88 \mathrm{kDa}$ monomer (Junaid et al., 2016). Intracellularacting VacA exhibits the characteristics of an $\mathrm{AB}$ toxin in which, however, the enzymatic activity of subunit $A$ is substituted by the pore-forming activity (Boquet and Ricci, 2012). The efficiency of the pore-forming activity inside the host cell is as potent as the enzymatic activity of canonical AB toxins. VacA actually targets the inner mitochondrial membrane, whose alteration is lethal for the cell (Wang and Youle, 2009). It has been shown that once inside gastric epithelial cells, VacA inserts itself into mitochondria, forms membrane channels and modulates the mitochondrial membrane permeability (Kimura et al., 1999; Kim and Blanke, 2012). This results in cytochrome $C$ release and the execution of apoptosis through an increase in the expression of cell cycle/apoptosis regulators such as p53, p2 ${ }^{\mathrm{Cip} 1}$ and Bax, beyond caspases- 8 and -9 , as was shown in vitro in gastric epithelial AGS cells (Manente et al., 2008; Palframan et al., 2012).

An exposure of cells to a recombinant VacA was associated with the inhibition of cell growth and resulted in morphological changes and DNA fragmentation; a cell cycle analysis revealed a prolongation of the cell cycle progression in the G1 phase (Kimura et al., 1999; Cho et al., 2003). These findings indicate that VacA of $H$. pylori induces apoptosis in gastric epithelial cells and suggests that VacA might mediate the development of gastric diseases through a cell cycle arrest in the G1 phase (Cho et al., 2003). Additionally, it was found that VacA can efficiently block the proliferation of $\mathrm{T}$ cells by inducing an arrest during the G1/S phase transition (Gebert et al., 2003). This influences the T cell receptor/interleukin-2 (IL-2) signaling pathway through the $\mathrm{Ca}^{2+}$-calmodulin-dependent phosphatase calcineurin, resulting in down-regulation of IL-2 transcription.

\section{Cytotoxic necrotizing factor}

The Cytotoxic Necrotizing Factor 1 (CNF-1) is a toxin produced by certain pathogenic $E$. coli. This toxin is associated with urinary tract infections as well as with skin and soft tissue infections, furthermore, CNF-1 produced by some pathogenic strains causes diarrheal illness (Table 1; Knust and Schmidt, 2010). E. coli CNF1 is a $113.8 \mathrm{kDa} \mathrm{AB}$ toxin comprising an $\mathrm{N}$-terminal receptorbinding domain, a binder domain with two hydrophobic helices involved in membrane translocation and a C-terminal catalytic domain (Kouokam et al., 2006; Lemonnier et al., 2007).

The first description of CNF-1 was associated with its ability to cause multinucleation, in vitro, in different cell lines (Caprioli et al., 1984). Investigations of molecular mechanisms of the action of CNF-1 demonstrated that CNF- 1 enters the cells by receptor-mediated endocytosis, which is independent of clathrin 
and of sphingolipid-cholesterol-rich membrane microdomains (Contamin et al., 2000). It was found that CNF-1 activates proteins belonging to the family of Rho GTPases (e.g., Rho, Rac, and $\mathrm{Cdc} 42$ ), by promoting deamidation of glutamine 63 of RhoA or the equivalent Q61 of Racl and Cdc42 and converts this residue into a glutamic acid (Flatau et al., 1997; Schmidt et al., 1997; Lerm et al., 1999). To target Rho GTPases, which are located in the cytosol and at the plasma membrane, the catalytic domain of CNF-1 has to be released from the endosomal membrane. Unlike other AB-toxins, autocatalytic cleavage was not identified, indicating that endosomal protease may be involved in CNF-1 processing (Knust et al., 2009; Knust and Schmidt, 2010). Beside a pivotal role in the regulation of intercellular junctions, in the coordination of the cell motility and in the adherence of polymorphonuclear leukocytes to epithelia, Rho GTPases, when activated, are essential for the internalization of apoptotic cells and for the induction of micropinocytosis (Fiorentini et al., 1995, 2001; Hofman et al., 2000; Wang et al., 2003; Knust and Schmidt, 2010).

Moreover, it was shown that CNF-1 prevents the CDK1Cyclin B1-dependent progression of cells from the G2 phase to the $M$ phase in uroepithelial cells (Falzano et al., 2006). It is recognized that Cyclin $\mathrm{B} 1$ expression varies during the cell cycle progression with the highest level in the G2/M phase. Cyclin $\mathrm{B} 1$ is essentially found in the cytoplasm region through the G2 phase until it translocates into the nucleus, which precedes the nuclear envelope breakdown (Falzano et al., 2006). It was demonstrated that CNF-1 reduces cyclin $\mathrm{B} 1$ expression and induces a sequestration of cyclin $\mathrm{B} 1$ in the cytoplasm that results in CDK1 inhibition and G2/M phase arrest (Falzano et al., 2006; Giamboi-Miraglia et al., 2007).

As in case of other cyclomodulins, CNF-1-induced G2/M arrest, which impairs epithelial layer turnover, might favor $E$. coli colonization and represent a long-term risk of carcinogenesis due, to some extent, to the capacity of Rho GTPases to promote a great number of events such as motility of tumorigenic cells, metastasis, cell invasiveness and abrogation of cytokinesis (Malorni and Fiorentini, 2006).

\section{Cyclomodulins without Enzymatic Activity Panton-Valentine leukocidin}

Staphylococcus aureus (S. aureus) is an opportunistic pathogen responsible for a wide panel of diseases ranging from skin and soft tissue infections to life-threatening systemic diseases in humans and animals. S. aureus frequently promotes infections by producing powerful toxins. Panton-Valentine leukocidin (PVL) is one of the $\beta$-pore-forming toxins associated with the increased virulence of certain $S$. aureus strains (Table 1). PVL is responsible for leukocyte destruction and necrotic hemorrhagic pneumonia, a highly lethal infection that essentially affects healthy children and young adults.

PVL is a bi-component toxin that acts due to the synergistic activity of two protein subunits, 33 and $34 \mathrm{kDa}$ in size, denoted as $\mathrm{S}$ and $\mathrm{F}$ according to their slow or fast elution in cationexchange carboxy-methyl cellulose chromatography (Bronner et al., 2004). These proteins are encoded by two co-transcribed genes, $l u k S-P V$ and $l u k F-P V$, which are located in a prophage
(McClure et al., 2006). LukS-PV and LukF-PV subunits with a beta-barrel structure acquire pore-forming conformation after binding to the C5A receptor (Spaan et al., 2013), followed by hetero-oligomerization in the plasma membrane of the host defense cells. An insertion of pores into the plasma membrane leads to ion influx and efflux followed by cell lysis (Aman and Adhikari, 2014).

It was observed that the LukS-PV subunit alone inhibits the proliferation of the human acute myeloid leukemia cell line THP-1 (Bu et al., 2013). The analysis of the cell cycle of LukS-PV-treated THP-1 cells showed cell cycle changes: LukS$\mathrm{PV}$ reduced the number of S-phase cells while increasing the number of G0/G1-phase cells. Moreover, LukS-PV significantly inhibited the expression of cyclin D1 that regulates the cell cycle progression from phase G1 to phase S (Lim and Kaldis, 2013). Collectively, these data suggest a LukS-PV-induced G0/G1 arrest.

\section{Phenol soluble modulins}

The phenol-soluble modulin (PSM) peptides were first identified in 1999 as a "pro-inflammatory complex" isolated by hot phenol extraction from S. epidermidis (Mehlin et al., 1999). PSMs have recently emerged as a novel toxin family that contributes to increased virulence and the spread of highly aggressive $S$. aureus isolates (Table 1; Otto, 2012; Peschel and Otto, 2013; Deplanche et al., 2016). Formed by amphipathic peptides arranged in alpha helices, PSMs are classified according to their size: short (20-25 amino acids) $\alpha$-type peptides (PSM $\alpha 1-P S M \alpha 4)$ and $\delta$-toxin, and long (44 amino acids) $\beta$-type peptides (PSM $\beta 1$ and PSM $\beta 2$ ) (Otto, 2014).

PSMs are encoded at three different locations in the genome. Four PSM $\alpha 1-\mathrm{PSM} \alpha 4$ peptides are encoded in the psm $\alpha$ operon; PSM $\beta 1$ and PSM $\beta 2$ are encoded in the $p \sin \beta$ operon; and $\delta$-toxin is encoded within the coding sequence for RNAIII, the effector of the accessory gene regulator (Agr) quorum-sensing system (Novick, 2003; Peschel and Otto, 2013).

PSMs have a multiplicity of biological functions that are essential to staphylococcal pathogenesis (Otto, 2012). PSMs trigger inflammatory responses such as chemotaxis and a priming of human neutrophils, and induce cytokine expression (Wang et al., 2007). It was found that PSMs inhibit interleukin expression during long-term infections, suggesting the involvement of PSMs in infection persistence (Deplanche et al., 2016). PSMs lyse white and red blood cells (Cassat et al., 2013) and contribute to the formation of biofilms (Periasamy et al., 2012). PSMs also present antimicrobial and immunomodulatory properties (Wang et al., 2007; Kretschmer et al., 2010; Joo et al., 2011).

We have demonstrated that the methicillin-resistant $S$. aureus MW2 induced both a decrease in the mitotic index and a cytopathic effect in host cells (Alekseeva et al., 2013). Moreover, we have shown that MW2 induces a G2/M phase transition delay in host cells, which was associated with the accumulation of the cyclin-dependent kinase $\mathrm{Cdk} 1 / \mathrm{cdc} 2$ and unphosphorylated histone H3. Recently, we determined that PSMs were responsible for the G2/M phase transition delay, suggesting that PSMs belong to a family of cyclomodulins. The PSM $\alpha$-induced G2/M phase delay was associated with an increased infective efficiency including bacterial internalization and bacterial intracellular 
multiplication, as well as with an decreased production of antibacterial peptides by the host cells (Deplanche et al., 2015).

\section{Non-proteinaceous Cyclomodulins Mycolactone}

The opportunistic pathogen Mycobacterium ulcerans is responsible for Buruli ulcer (BU), an infectious disease, which is characterized by tissue necrosis and immunosuppression (Demangel et al., 2009). The macrolide mycolactone produced by $M$. ulcerans, was found to be the necessary and sufficient virulence factor for BU pathology (Table 1). Mycolactone consists of two polyketide chains, one of which forms the core lactone, a 12-member lactone ring, resulting in spontaneous cyclization (Fidanze et al., 2001).

Mycolactone-induced immunosuppression was found to be associated with the prevention of the translocation of proteins that pass through the endoplasmic reticulum before secretion (Sarfo et al., 2016). Consequently, this effect impairs the immune functions of various host cells such as monocytes, macrophages, $\mathrm{T}$ cells and dendritic cells that interact with mycolactone during an infection (Phillips et al., 2009; Simmonds et al., 2009). It was reported that the core lactone was sufficient for cytotoxicity of mycolactone, while the fatty acid side chain allows mycolactone to enter the host cells, enabling its interaction with intracellular target molecules (Mve-Obiang et al., 2003).

It was found that Wiskott-Aldrich syndrome protein (WASP) and neural WASP (N-WASP) are molecular targets of mycolactone (Guenin-Macé et al., 2013). WASP and N-WASP are members of a family of scaffold proteins, transducing a variety of signals and triggering the remodeling of the actin cytoskeleton (Thrasher and Burns, 2010). Mycolactone activates WASP and N-WASP through the disruption of the intermolecular interaction by a variety of ligands including the cell cycle regulator CDC42. Activation of WASP and N-WASP with a low dose mycolactone was associated to a cell cycle arrest in the G0/G1 phase resulting in apoptosis (George et al., 2000; Gama et al., 2014). The cell cycle and apoptosis are indeed interrelated: cells, which detect an alteration of cell cycle progression, can undergo apoptosis.

\section{ALTERATION OF THE HOST CELL CYCLE AS A BENEFICIAL FEATURE FOR BACTERIAL FITNESS}

Cyclomodulins present a wide array of action on diverse cellular transduction pathways, and thus would provide cyclomodulinproducing bacteria with a noteworthy fitness advantage against a eukaryotic host defenses as well as against bacterial competitors for the colonization site. Figure 4 presents a few examples of such cyclomodulin actions that are discussed hereafter.

Thus, E. coli-produced toxin, CNF, which is shown to induce the G2/M transition delay during infection, probably impairs the host epithelial layer turnover and, therefore, favors bacterial colonization (Figure 4; Falzano et al., 2006). Another E. coli toxin, CIF, which is produced by EPEC, EHEC and other (entero) pathogenic strains, induces the arrest of the

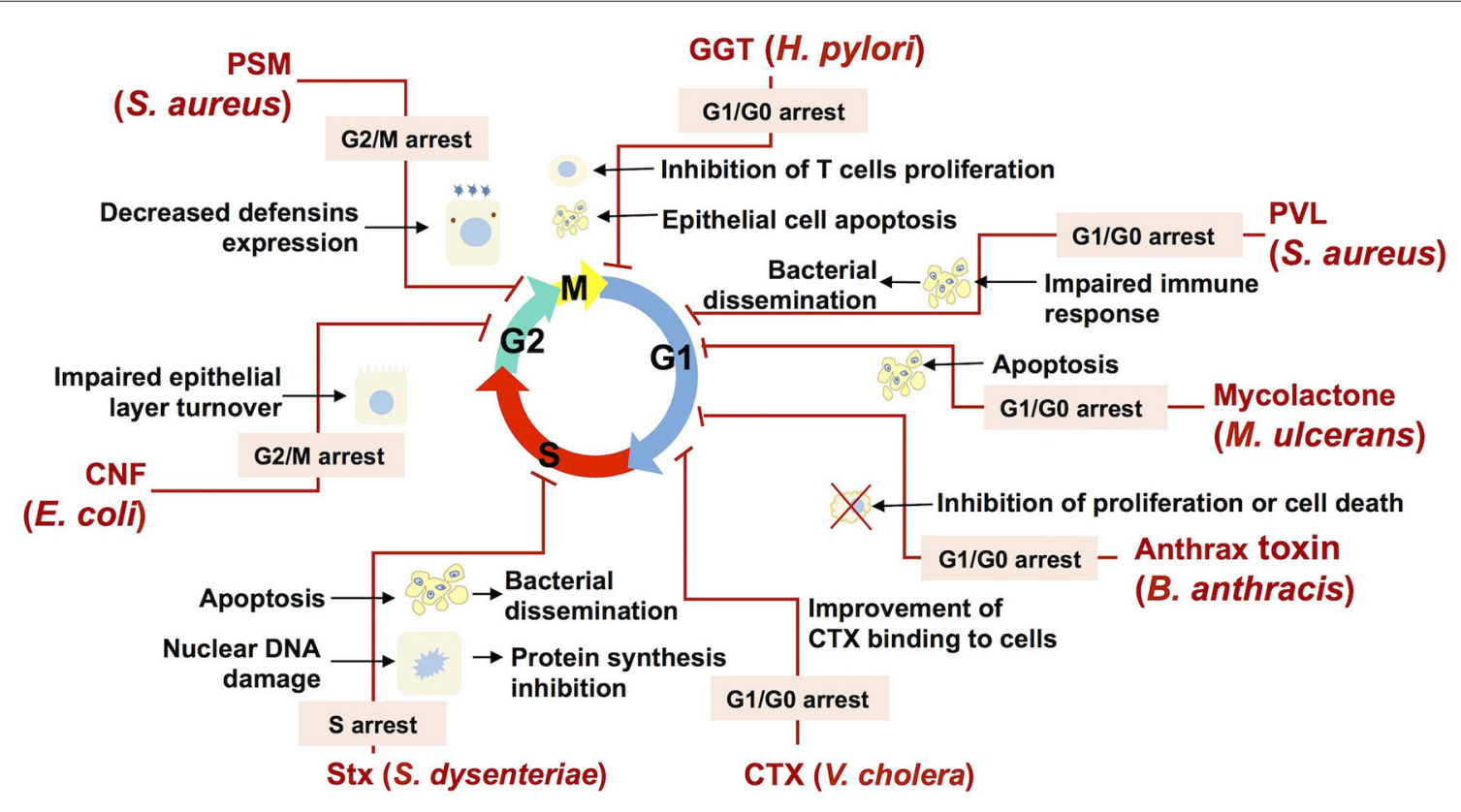

FIGURE 4 | Bacterial cyclomodulins alter the eukaryotic cell cycle for their own benefit. The names of bacteria and the abbreviations of cyclomodulins produced by those bacteria are indicated in red. Cell cycle phases are indicated by colored arrows. Zigzag red lines are attached to the phase in which the cell cycle is blocked by the corresponding cyclomodulin. The phases in which the cell cycle is blocked are indicated in an appropriate text insert. Black arrows display the biological effects related to the cyclomodulin-induced cell cycle arrest. 
G2 and the G1 phases of the cell cycle, which is correlated with the accumulation of the CDK inhibitors, $\mathrm{p} 21^{\text {cip } 1}$ and p27 $7^{\text {kip } 1}$. These CDK inhibitors are involved in cell cycle exit, differentiation, carcinogenesis and survival. Consequently, it is hypothesized that CIF prolongs both bacterial attachment and local persistence by slowing down a crypt-villus cell renewal (Taieb et al., 2006; Samba-Louaka et al., 2009a). Recently, it was shown that CIF is a bona fide virulence factor as its mutation attenuates the pathogenic potential of Yersinia pseudotuberculosis in a mouse infection model by blocking the bactericidal activity of Perforin-2 (McCormack et al., 2015). $H$. pylori GGT, which induces the G1 phase arrest, can trigger apoptosis in gastric epithelial cells, which in turn may result in impaired protective functions of gastric epithelium and contribute to gastric injury during $H$. pylori infection (Ricci et al., 2014). In addition to epithelial cells, it was shown that $\mathrm{T}$ cells are also subject G1 phase arrest, suggesting that GGT may contribute to immune evasion during $H$. pylori infection through the modulation of T cell-mediated immunity (Figure 4; Schmees et al., 2007).

The $M$. ulcerans mycolactone induces a G0/G1 cell cycle phase arrest via a remodeling of the actin cytoskeleton resulting in apoptosis (George et al., 2000; Gama et al., 2014). Mycolactoneinduced apoptosis likely play a role in BU pathology. In particular, the release of internalized bacteria from apoptotic cells will prone to a bacterial dissemination within the host (George et al., 2000). Moreover, mycolactone-induced apoptosis of human peripheral blood leukocytes leads to the depletion of $\mathrm{T}$ cells resulting in a suppression of a local immune response (Figure 4; Fraga et al., 2011).

S. aureus, which commonly infects epithelial surfaces and leads to abscess formation, necrosis and a compromised integrity of the host epithelial barrier, is also known to cause morphological changes in epithelial cells such as cell enlargement and increase in nucleus size, and decrease of host cell proliferation (Alekseeva et al., 2013). An S. aureus-induced decrease of the host cell proliferation was associated with the G2/M transition delay, which was triggered by PSMs (Deplanche et al., 2015). A PSM $\alpha$-induced delay results in an augmented staphylococcal internalization and in an enhanced intracellular proliferation, which have been shown to be more effective in $\mathrm{G} 2 / \mathrm{M}$ phase cells than in asynchronous cells. Moreover, a PSM $\alpha$-induced delay correlates with an alteration in defensins (antibacterial peptides) gene expression, with a lower expression when the cells were in the G2/M phase. This reduction of the antibacterial functions of epithelial cells demonstrates the advantage of a PSM $\alpha$-induced cell cycle delay for the infection of host cells by S. aureus (Deplanche et al., 2015). Beyond this particular example, cell cycle arrest is likely to be used by many bacteria in order to inhibit the host defense mechanisms (Figure 4).

Leukocidin, an another $S$. aureus toxin, was shown to induce a cell cycle arrest followed by apoptosis (Bu et al., 2013) of a THP-1 cells, the common model to study monocyte and macrophage activities (Chanput et al., 2014). This finding suggests that leukocidin may be involved in the modulation of the immune response during $S$. aureus infection via a destruction of monocytes and macrophages, which favors bacterial dissemination (Figure 4). The capacity of anthrax toxin, produced by $B$. anthracis, to inhibit cell cycle progress in melanocytes (Koo et al., 2002) and monocytic cell lines (Kassam et al., 2005) may also impair defense mechanisms and contribute to the survival and the proliferation of $B$. anthracis within the host (Figure 4).

Bacteria can inhibit host defense mechanisms via a modification of cytokines production induced by the alteration of cells proliferation and differentiation. It was indeed shown that $H$. pylori VacA toxin induces G1/S arrest in T lymphocytes and that it results in a down regulation of cytokines involved in host defense. The capacity of VacA to induce a local immune suppression may explain the chronicity of $H$. pylori infections (Gebert et al., 2003). CDT of A. actinomycetemcomitans, which induces cell cycle arrest of periodontal fibroblasts, oral epithelial cells or T-lymphocytes in the periodontal environment, deregulates the local immune response and facilitates the bacterial invasion (Belibasakis et al., 2005a,b, 2008; Belibasakis and Bostanci, 2014). Furthermore, it was demonstrated that the ACT cyclomodulins produced by Bordetella species and $B$. anthracis are capable of interfering with the proliferation and the differentiation of $\mathrm{T}$ cells, reducing the production of TNF- $\alpha$ and increasing the production of IL-10 in dendritic cells (Vojtova et al., 2006; Rossi Paccani and Baldari, 2011). The continuous production of ACT during an infection triggers mechanisms that compromise the inflammatory response by inhibiting the regeneration of populations of defense cells (Chou et al., 2008; Gray and Hewlett, 2011). Moreover, ACT was recently found to promote the internalization of bacteria in non-phagocytic cells (Martín et al., 2015). It is likely that an ACT-related increase of bacterial internalization is associated with an ACT-induced cell cycle alteration, similar to that of staphylococcal PSMs.

Bacterial toxins may alter the eukaryotic cell cycle in order to improve their capacity to adhere to and to be internalized by target cells. It was demonstrated that CTX bind to the cell surface via glycolipid receptors GM1, whose highest expression takes place during interphase and the G1 phase (Majoul et al., 2002). Consequently, CTX-induced arrest of cells in the G1 phase amplifies the action of CTX (Figure 4).

A number of toxins with the ability to inhibit different stages of protein synthesis in eukaryotic cells are commonly found in nature (Lemaitre and Girardin, 2013). SubAB and Stx are some of them. While SubAB inhibits the production of pro-inflammatory cytokines and chemokines during infection, Stx, which is also involved in the inhibition of protein synthesis, induces an inflammatory response (Wang et al., 2011). Both SubAB and Stx have been reported to cause cell cycle delay as well as apoptosis (Figure 4; Márquez et al., 2014). A cell cycle delay might be beneficial for an intracellular bacterial establishment due to impaired cellular activity. Moreover the induction of apoptosis likely helps to disperse bacteria within the host as a result of the release of bacteria from apoptotic cells, followed by their migration to other host cells (Gao and Kwaik, 2000; Bergan et al., 2012). 
Some bacterial effectors, like the CDT family of toxins produced by a number of unrelated Gram-negative species, lead to cell cycle arrest through their ability to induce chromatin injury. After DNA damage, CDT activates the DNA repair response partly through the ATM kinase that modulates the activation of cell cycle checkpoints, leading to cell type-dependent cell cycle arrest (Arbibe, 2008). The resulting cell cycle arrest alters epithelial cell turnover and thus promotes bacterial colonization. Additionally, bacteria-induced long-lasting DNA damage can result in genetic instability and prone the development of cancer.

Epigenetic modifications that may arise from bacteriainduced injury of chromatin, which maintains the stability and the accessibility of the host genome to the transcriptional machinery (Arbibe, 2008; Bierne and Cossart, 2012), are the focal point of an emerging topic in the field of host-pathogen interactions. There is only limited knowledge as of yet about microbial factors that induce epigenetic modifications which make it possible to impose a pathogen transcriptional signature onto host cells and shape the host immune response (Arbibe, 2008). Consequently, since cyclomodulins are able to induce DNA damage and cell cycle arrest, the following intriguing question is raised: are bacterial cyclomodulins able to promote epigenetic alterations in host cells?

\section{CONCLUDING REMARKS}

Bacterial cyclomodulins are a growing and heterogeneous family of virulence factors that not only alter host cell cycle progression, but that also interfere with typical host cell activity, including cell differentiation and development that slow down cell and tissue renewal. These actions should be further investigated in in vivo models and they might favor host colonization and allow the bacteria to hijack host cell protective functions for their own benefit. Thus, an alteration of the eukaryotic cell cycle might enhance the infective efficiency of bacterial pathogens. It should also be emphasized

\section{REFERENCES}

Ahn, J., Urist, M., and Prives, C. (2004). The Chk2 protein kinase. DNA Rep. 3, 1039-1047. doi: 10.1016/j.dnarep.2004.03.033.

Akifusa, S., Poole, S., Lewthwaite, J., Henderson, B., and Nair, S. P. (2001). Recombinant Actinobacillus actinomycetemcomitans cytolethal distending toxin proteins are required to interact to inhibit human cell cycle progression and to stimulate human leukocyte cytokine synthesis. Infect. Immun. 69, 5925-5930. doi: 10.1128/iai.69.9.5925-5930.2001

Alekseeva, L., Rault, L., Almeida, S., Legembre, P., Edmond, V., Azevedo, V., et al. (2013). Staphylococcus aureus-induced G2/M phase transition delay in host epithelial cells increases bacterial infective efficiency. PLoS ONE 8:e63279. doi: 10.1371/journal.pone.0063279

Alto, N. M., and Orth, K. (2012). Subversion of Cell Signaling by Pathogens. Cold Spring Harb. Perspect. Biol. 4:a006114. doi: 10.1101/cshperspect.a006114

Aman, M. J., and Adhikari, R. P. (2014). Staphylococcal bicomponent poreforming toxins: targets for prophylaxis and immunotherapy. Toxins 6, 950-972. doi: 10.3390/toxins6030950

Anderson, J. D., MacNab, A. J., Gransden, W. R., Damm, S. M., Johnson, W. M., and Lior, H. (1987). Gastroenteritis and encephalopathy associated with that bacteria-induced long-lasting DNA damage may induce genetic instability and lead to the development of cancer. Cyclomodulin structures and the mechanisms of bacteriainduced cell cycle alterations dramatically vary depending on the type of bacteria. Most cyclomodulins consist of proteins, but the presence of non-proteinaceous effectors highlight the capacity of bacteria to develop a wide range of toxins with distinct molecular compositions, but with similar actions leading to the enhancement of their fitness during infection. The study of cyclomodulins is an emerging field of research and additional modulins might be identified in a near future. Deciphering the molecular mechanisms by which cyclomodulins hijack the main host cell function, the cell cycle progression, and decoding consequences of such an alteration will ultimately provide us with clues for better understanding the fundamental stages of the host-pathogen interaction, as well as with new targets for the development of therapeutic approaches of bacterial infections.

\section{AUTHOR CONTRIBUTIONS}

$\mathrm{RF}, \mathrm{AN}$, and TC wrote the manuscript. AN, YL, MD, and $\mathrm{NB}$ composed the figure and created the table. YL, FT, PG, and GL discussed the data and contributed to the writing of the manuscript. VA commented on the manuscript. NB conceived, directed, and contributed to the writing of the manuscript.

\section{ACKNOWLEDGMENTS}

The authors thank Gail Wagman and Mary Bret for revising the English. This work was supported by the French National Institute for Agricultural Research (INRA), Ruminflame P10552 (to $\mathrm{NB}, \mathrm{MD}$, and $\mathrm{YL}$ ), ERA-NET ANIHWA KOLIMASTIR, Convention ANR-13-ANWA-0003-06 (to NB and MD), RE is a recipient of a Ph.D. fellowship from Coordenação de Aperfeiçoamento de Pessoal de Nivel Superior (CAPES; Brazil). a strain of Escherichia coli $055: \mathrm{K} 59: \mathrm{H} 4$ that produced a cytolethal distending toxin. Pediatr. Infect. Dis. J. 6, 1135-1136

Arbibe, L. (2008). Immune subversion by chromatin manipulation: a "new face" of host-bacterial pathogen interaction. Cell. Microbiol. 10, 1582-1590. doi: 10.1111/j.1462-5822.2008.01170.x

Ascenzi, P., Visca, P., Ippolito, G., Spallarossa, A., Bolognesi, M., and Montecucco, C. (2002). Anthrax toxin: a tripartite lethal combination1. FEBS Lett. 531, 384-388. doi: 10.1016/S0014-5793(02)03609-8

Ashida, H., Ogawa, M., Kim, M., Mimuro, H., and Sasakawa, C. (2012). Bacteria and host interactions in the gut epithelial barrier. Nat. Chem. Biol. 8, 36-45. doi: $10.1038 /$ nchembio.741

Bachelet, M., Richard, M.-J., François, D., and Polla, B. S. (2002). Mitochondrial alterations precede Bordetella pertussis -induced apoptosis. FEMS Immunol. Med. Microbiol. 32, 125-131. doi: 10.1111/j.1574-695X.2002.tb00544.x

Balskus, E. P. (2015). Colibactin: understanding an elusive gut bacterial genotoxin. Nat. Prod. Rep. 32, 1534-1540. doi: 10.1039/c5np00091b

Basler, M., Masin, J., Osicka, R., and Sebo, P. (2006). Pore-forming and enzymatic activities of Bordetella pertussis adenylate cyclase toxin synergize in promoting lysis of monocytes. Infect. Immun. 74, 2207-2214. doi: 10.1128/IAI.74.4.2207-2214.2006 
Belibasakis, G. N., and Bostanci, N. (2014). Inflammatory and bone remodeling responses to the cytolethal distending toxins. Cells 3, 236-246. doi: $10.3390 /$ cells 3020236

Belibasakis, G. N., Brage, M., Lagergård, T., and Johansson, A. (2008). Cytolethal distending toxin upregulates RANKL expression in Jurkat Tcells. APMIS Acta Pathol. Microbiol. Immunol. Scand. 116, 499-506. doi: 10.1111/j.1600-0463.2008.01017.x

Belibasakis, G. N., Johansson, A., Wang, Y., Chen, C., Kalfas, S., and Lerner, U. H. (2005a). The cytolethal distending toxin induces receptor activator of Nf- B ligand expression in human gingival fibroblasts and periodontal ligament cells. Infect. Immun. 73, 342-351. doi: 10.1128/IAI.73.1.342-351.2005

Belibasakis, G. N., Johansson, A., Wang, Y., Chen, C., Lagergård, T., Kalfas, S., et al. (2005b). Cytokine responses of human gingival fibroblasts to Actinobacillus actinomycetemcomitans cytolethal distending toxin. Cytokine 30, 56-63. doi: 10.1016/j.cyto.2004.11.008

Bergan, J., Dyve Lingelem, A. B., Simm, R., Skotland, T., and Sandvig, K. (2012). Shiga toxins. Toxicon 60, 1085-1107. doi: 10.1016/j.toxicon.2012.07.016

Bezine, E., Vignard, J., and Mirey, G. (2014). The cytolethal distending toxin effects on mammalian cells: a DNA damage perspective. Cells 3, 592-615. doi: $10.3390 /$ cells3020592

Bhattacharjee, R. N., Park, K.-S., Uematsu, S., Okada, K., Hoshino, K., Takeda, K., et al. (2005). Escherichia coli verotoxin 1 mediates apoptosis in human HCT116 colon cancer cells by inducing overexpression of the GADD family of genes and S phase arrest. FEBS Lett. 579, 6604-6610. doi: 10.1016/j.febslet.2005.10.053

Bhavsar, A. P., Guttman, J. A., and Finlay, B. B. (2007). Manipulation of host-cell pathways by bacterial pathogens. Nature 449, 827-834. doi: 10.1038 /nature 06247

Bierne, H., and Cossart, P. (2012). When bacteria target the nucleus: the emerging family of nucleomodulins. Cell. Microbiol. 14, 622-633. doi: 10.1111/j.1462-5822.2012.01758.x

Boquet, P., and Ricci, V. (2012). Intoxication strategy of Helicobacter pylori VacA toxin. Trends Microbiol. 20, 165-174. doi: 10.1016/j.tim.2012.01.008

Bradley, K. A., Mogridge, J., Mourez, M., Collier, R. J., and Young, J. A. T. (2001). Identification of the cellular receptor for anthrax toxin. Nature 414, 225-229. doi: $10.1038 / \mathrm{n} 35101999$

Bronner, S., Monteil, H., and Prévost, G. (2004). Regulation of virulence determinants in Staphylococcus aureus: complexity and applications. FEMS Microbiol. Rev. 28, 183-200. doi: 10.1016/j.femsre.2003.09.003

Bu, S., Xie, Q., Chang, W., Huo, X., Chen, F., and Ma, X. (2013). LukS-PV induces mitochondrial-mediated apoptosis and G0/G1 cell cycle arrest in human acute myeloid leukemia THP-1 cells. Int. J. Biochem. Cell Biol. 45, 1531-1537. doi: 10.1016/j.biocel.2013.05.011

Busiello, I., Acquaviva, R., Di Popolo, A., Blanchard, T. G., Ricci, V., Romano, M., et al. (2004). Helicobacter pylori $\gamma$-glutamyltranspeptidase upregulates COX-2 and EGF-related peptide expression in human gastric cells. Cell. Microbiol. 6, 255-267. doi: 10.1046/j.1462-5822.2004.00366.x

Caprioli, A., Donelli, G., Falbo, V., Possenti, R., Roda, L. G., Roscetti, G., et al. (1984). A cell division-active protein from E. coli. Biochem. Biophys. Res. Commun. 118, 587-593. doi: 10.1016/0006-291X(84)91343-3

Carbonetti, N. H. (2010). Pertussis toxin and adenylate cyclase toxin: key virulence factors of Bordetella pertussis and cell biology tools. Future Microbiol. 5, 455-469. doi: 10.2217/fmb.09.133

Cassat, J. E., Hammer, N. D., Campbell, J. P., Benson, M. A., Perrien, D. S., Mrak, L. N., et al. (2013). A secreted bacterial protease tailors the Staphylococcus aureus virulence repertoire to modulate bone remodeling during osteomyelitis. Cell Host Microbe 13, 759-772. doi: 10.1016/j.chom.2013.05.003

Chanput, W., Mes, J. J., and Wichers, H. J. (2014). THP-1 cell line: an in vitro cell model for immune modulation approach. Int. Immunopharmacol. 23, 37-45. doi: 10.1016/j.intimp.2014.08.002

Chen, Y., Yang, Z., Meng, M., Zhao, Y., Dong, N., Yan, H., et al. (2009). Cullin Mediates degradation of RhoA through evolutionarily conserved BTB adaptors to control actin cytoskeleton structure and cell movement. Mol. Cell 35, 841-855. doi: 10.1016/j.molcel.2009.09.004

Cho, S.-J., Kang, N.-S., Park, S.-Y., Kim, B.-O., Rhee, D.-K., and Pyo, S. (2003). Induction of apoptosis and expression of apoptosis related genes in human epithelial carcinoma cells by Helicobacter pylori VacA toxin. Toxicon 42, 601611. doi: 10.1016/j.toxicon.2003.08.003
Chou, P.-J., Newton, C. A., Perkins, I., Friedman, H., and Klein, T. W. (2008), Suppression of dendritic cell activation by anthrax lethal toxin and edema toxin depends on multiple factors including cell source, stimulus used, and function tested. DNA Cell Biol. 27, 637-648. doi: 10.1089/dna.2008.0760

Contamin, S., Galmiche, A., Doye, A., Flatau, G., Benmerah, A., and Boquet, P. (2000). The p21 Rho-activating toxin cytotoxic necrotizing factor 1 is endocytosed by a clathrin-independent mechanism and enters the cytosol by an acidic-dependent membrane translocation step. Mol. Biol. Cell 11, 1775-1787. doi: $10.1091 / \mathrm{mbc}$.11.5.1775

Cortes-Bratti, X., Karlsson, C., Lagergård, T., Thelestam, M., and Frisan, T. (2001). The Haemophilus ducreyi cytolethal distending toxin induces cell cycle arrest and apoptosis via the DNA damage checkpoint pathways. J. Biol. Chem. 276, 5296-5302. doi: 10.1074/jbc.M008527200

Cover, T. L., and Blaser, M. J. (1992). Purification and characterization of the vacuolating toxin from Helicobacter pylori. J. Biol. Chem. 267, 10570-10575.

Cui, J., Yao, Q., Li, S., Ding, X., Lu, Q., Mao, H., et al. (2010). Glutamine deamidation and dysfunction of Ubiquitin/NEDD8 by a bacterial effector family. Science 329, 1215-1218. doi: 10.1126/science.1193844

Demangel, C., Stinear, T. P., and Cole, S. T. (2009). Buruli ulcer: reductive evolution enhances pathogenicity of Mycobacterium ulcerans. Nat. Rev. Microbiol. 7, 50-60. doi: 10.1038/nrmicro2077

Deplanche, M., Alekseeva, L., Semenovskaya, K., Fu, C.-L., Dessauge, F., Finot, L., et al. (2016). Staphylococcus aureus phenol-soluble modulins impair interleukin expression in bovine mammary epithelial cells. Infect. Immun. 84, 1682-1692. doi: 10.1128/IAI.01330-15

Deplanche, M., Filho, R. A. E.-A., Alekseeva, L., Ladier, E., Jardin, J., Henry, G., et al. (2015). Phenol-soluble modulin $\alpha$ induces G2/M phase transition delay in eukaryotic HeLa cells. FASEB J. 29, 1950-1959. doi: 10.1096/fj.14-260513

Ding, S.-Z., Minohara, Y., Fan, X. J., Wang, J., Reyes, V. E., Patel, J., et al. (2007). Helicobacter pylori infection induces oxidative stress and programmed cell death in human gastric epithelial cells. Infect. Immun. 75, 4030-4039. doi: 10.1128/IAI.00172-07

DiRienzo, V. (2014). Cytolethal distending toxin: a unique variation on the $\mathrm{AB}$ toxin paradigm. New J. Sci. 2014:e249056. doi: 10.1155/2014/249056

Eby, J. C., Ciesla, W. P., Hamman, W., Donato, G. M., Pickles, R. J., Hewlett, E. L., et al. (2010). Selective Translocation of the Bordetella pertussis adenylate cyclase toxin across the basolateral membranes of polarized epithelial cells. J. Biol. Chem. 285, 10662-10670. doi: 10.1074/jbc.M109.089219

Elwell, C. A., and Dreyfus, L. A. (2000). DNase I homologous residues in CdtB are critical for cytolethal distending toxin-mediated cell cycle arrest. Mol. Microbiol. 37, 952-963. doi: 10.1046/j.1365-2958.2000.02070.x

Falzano, L., Filippini, P., Travaglione, S., Miraglia, A. G., Fabbri, A., and Fiorentini, C. (2006). Escherichia coli cytotoxic necrotizing factor 1 blocks cell cycle G2/M transition in uroepithelial cells. Infect. Immun. 74, 3765-3772. doi: 10.1128/IAI.01413-05

Farrokh, C., Jordan, K., Auvray, F., Glass, K., Oppegaard, H., Raynaud, S., et al. (2013). Review of Shiga-toxin-producing Escherichia coli (STEC) and their significance in dairy production. Int. J. Food Microbiol. 162, 190-212. doi: 10.1016/j.ijfoodmicro.2012.08.008

Fidanze, S., Song, F., Szlosek-Pinaud, M., Small, P. L. C., and Kishi, Y. (2001). Complete structure of the mycolactones. J. Am. Chem. Soc. 123, 10117-10118. doi: $10.1021 /$ ja011824z

Fiorentini, C., Donelli, G., Matarrese, P., Fabbri, A., Paradisi, S., and Boquet, P. (1995). Escherichia coli cytotoxic necrotizing factor 1: evidence for induction of actin assembly by constitutive activation of the p 21 Rho GTPase. Infect. Immun. 63, 3936-3944

Fiorentini, C., Falzano, L., Fabbri, A., Stringaro, A., Logozzi, M., Travaglione, S., et al. (2001). Activation of Rho GTPases by cytotoxic necrotizing factor 1 induces macropinocytosis and scavenging activity in epithelial cells. Mol. Biol. Cell 12, 2061-2073. doi: 10.1091/mbc.12.7.2061

Flatau, G., Lemichez, E., Gauthier, M., Chardin, P., Paris, S., Fiorentini, C., et al. (1997). Toxin-induced activation of the $G$ protein $p 21$ Rho by deamidation of glutamine. Nature 387, 729-733. doi: 10.1038/42743

Fraga, A. G., Cruz, A., Martins, T. G., Torrado, E., Saraiva, M., Pereira, D. R., et al. (2011). Mycobacterium ulcerans triggers T-cell immunity followed by local and regional but not systemic immunosuppression. Infect. Immun. 79, 421-430. doi: 10.1128/IAI.00820-10 
Friebe, S., van der Goot, F. G., and Bürgi, J. (2016). The ins and outs of anthrax toxin. Toxins 8:69. doi: 10.3390/toxins 8030069

Gama, J. B., Ohlmeier, S., Martins, T. G., Fraga, A. G., Sampaio-Marques, B., Carvalho, M. A., et al. (2014). Proteomic analysis of the action of the Mycobacterium ulcerans toxin mycolactone: targeting host cells cytoskeleton and collagen. PLoS Negl. Trop Dis. 8:e3066. doi: 10.1371/journal.pntd.0003066

Gao, L.-Y., and Kwaik, Y. A. (2000). The modulation of host cell apoptosis by intracellular bacterial pathogens. Trends Microbiol. 8, 306-313. doi: 10.1016/S0966-842X(00)01784-4

Gargi, A., Reno, M., and Blanke, S. R. (2012). Bacterial toxin modulation of the eukaryotic cell cycle: are all cytolethal distending toxins created equally? Front. Cell. Infect. Microbiol. 2:124. doi: 10.3389/fcimb.2012.00124

Ge, Z., Rogers, A. B., Feng, Y., Lee, A., Xu, S., Taylor, N. S., et al. (2007). Bacterial cytolethal distending toxin promotes the development of dysplasia in a model of microbially induced hepatocarcinogenesis. Cell. Microbiol. 9, 2070-2080. doi: 10.1111/j.1462-5822.2007.00939.x

Ge, Z., Schauer, D. B., and Fox, J. G. (2008). In vivo virulence properties of bacterial cytolethal-distending toxin. Cell. Microbiol. 10, 1599-1607. doi: 10.1111/j.1462-5822.2008.01173.x

Gebert, B., Fischer, W., Weiss, E., Hoffmann, R., and Haas, R. (2003). Helicobacter pylori vacuolating cytotoxin inhibits T lymphocyte activation. Science 301, 1099-1102. doi: 10.1126/science.1086871

George, K. M., Pascopella, L., Welty, D. M., and Small, P. L. C. (2000). A Mycobacterium ulcerans toxin, mycolactone, causes apoptosis in guinea pig ulcers and tissue culture cells. Infect. Immun. 68, 877-883. doi: 10.1128/iai.68.2.877-883.2000

Giamboi-Miraglia, A., Travaglione, S., Filippini, P., Fabbri, A., Fiorentini, C., and Falzano, L. (2007). A multinucleating Escherichia coli cytotoxin perturbs cell cycle in cultured epithelial cells. Toxicol. In vitro 21, 235-239. doi: 10.1016/j.tiv.2006.08.013

Glaser, P., Sakamoto, H., Bellalou, J., Ullmann, A., and Danchin, A. (1988). Secretion of cyclolysin, the calmodulin-sensitive adenylate cyclase-haemolysin bifunctional protein of Bordetella pertussis. EMBO J. 7, 3997-4004.

Gong, M., Ling, S. S. M., Lui, S. Y., Yeoh, K. G., and Ho, B. (2010). Helicobacter pylori $\gamma$-glutamyl transpeptidase is a pathogenic factor in the development of peptic ulcer disease. Gastroenterology 139, 564-573. doi: 10.1053/j.gastro.2010.03.050

Graillot, V., Dormoy, I., Dupuy, J., Shay, J. W., Huc, L., Mirey, G., et al. (2016). Genotoxicity of Cytolethal Distending Toxin (CDT) on isogenic human colorectal cell lines: potential promoting effects for colorectal carcinogenesis. Front. Cell. Infect. Microbiol. 6:34. doi: 10.3389/fcimb.2016.00034

Grant, G. D., Brooks, L., Zhang, X., Mahoney, J. M., Martyanov, V., Wood, T. A., et al. (2013). Identification of cell cycle-regulated genes periodically expressed in $\mathrm{U} 2 \mathrm{OS}$ cells and their regulation by FOXM1 and E2F transcription factors. Mol. Biol. Cell 24, 3634-3650. doi: 10.1091/mbc.E13-05-0264

Grasso, F., and Frisan, T. (2015). Bacterial genotoxins: merging the DNA damage response into infection biology. Biomolecules 5, 1762-1782. doi: 10.3390/biom5031762

Gray, M. C., and Hewlett, E. L. (2011). Cell cycle arrest induced by the bacterial adenylate cyclase toxins from Bacillus anthracis and Bordetella pertussis: adenylate cyclase toxins and cell cycle progression. Cell. Microbiol. 13, 123-134. doi: 10.1111/j.1462-5822.2010.01525.x

Guenin-Macé, L., Veyron-Churlet, R., Thoulouze, M.-I., Romet-Lemonne, G., Hong, H., Leadlay, P. F., et al. (2013). Mycolactone activation of WiskottAldrich syndrome proteins underpins Buruli ulcer formation. J. Clin. Invest. 123, 1501-1512. doi: 10.1172/JCI66576

Guermonprez, P., Khelef, N., Blouin, E., Rieu, P., Ricciardi-Castagnoli, P., Guiso, N., et al. (2001). The adenylate cyclase toxin of Bordetella pertussis binds to target cells via the $\alpha_{M} \beta_{2 g f}$ integrin (CD11b/CD18). J. Exp. Med. 193, 1035-1044. doi: 10.1084/jem.193.9.1035

Guerra, L., Cortes-Bratti, X., Guidi, R., and Frisan, T. (2011). The biology of the cytolethal distending toxins. Toxins 3, 172-190. doi: 10.3390/toxins 3030172

Guerra, L., Teter, K., Lilley, B. N., Stenerlšw, B., Holmes, R. K., Ploegh, H. L., et al. (2005). Cellular internalization of cytolethal distending toxin: a new end to a known pathway. Cell. Microbiol. 7, 921-934. doi: 10.1111/j.1462-5822.2005.00520.x

Ha, S.-D., Ng, D., Pelech, S. L., and Kim, S. O. (2007). Critical Role of the Phosphatidylinositol 3-Kinase/Akt/Glycogen Synthase Kinase-3 $\beta$ Signaling
Pathway in Recovery from Anthrax Lethal Toxin-induced Cell Cycle Arrest and MEK Cleavage in Macrophages. Available online at: http://www.jbc.org (Accessed August 18, 2015).

Hofman, P., Le Negrate, G., Mograbi, B., Hofman, V., Brest, P., AllianaSchmid, A., et al. (2000). Escherichia coli cytotoxic necrotizing factor-1 (CNF1) increases the adherence to epithelia and the oxidative burst of human polymorphonuclear leukocytes but decreases bacteria phagocytosis. J. Leukoc. Biol. 68, 522-528.

Hsu, Y., Jubelin, G., Taieb, F., Nougayrède, J.-P., Oswald, E., and Stebbins, C. E. (2008). Structure of the cyclomodulin Cif from pathogenic Escherichia coli. J. Mol. Biol. 384, 465-477. doi: 10.1016/j.jmb.2008.09.051

Huibregtse, J., and Rohde, J. R. (2014). Hell's BELs: Bacterial E3 Ligases that exploit the eukaryotic ubiquitin machinery. PLOS Pathog. 10:e1004255. doi: 10.1371/journal.ppat.1004255

Jain, D., Prasad, K. N., Sinha, S., and Husain, N. (2008). Differences in virulence attributes between cytolethal distending toxin positive and negative Campylobacter jejuni strains. J. Med. Microbiol. 57, 267-272. doi: 10.1099/jmm.0.47317-0

Jandhyala, D. M., Ahluwalia, A., Obrig, T., and Thorpe, C. M. (2008). ZAK: a MAP3Kinase that transduces Shiga toxin- and ricin-induced proinflammatory cytokine expression. Cell. Microbiol. 10, 1468-1477. doi: 10.1111/j.1462-5822.2008.01139.x

Johannes, L., and Romer, W. (2010). Shiga toxins-from cell biology to biomedical applications. Nat. Rev. Microbiol. 8, 105-116. doi: 10.1038/nrmicro2279

Joo, H.-S., Cheung, G. Y. C., and Otto, M. (2011). Antimicrobial activity of community-associated methicillin-resistant Staphylococcus aureus is caused by phenol-soluble modulin derivatives. J. Biol. Chem. 286, 8933-8940. doi: 10.1074/jbc.M111.221382

Jubelin, G., Chavez, C. V., Taieb, F., Banfield, M. J., Samba-Louaka, A., Nobe, R., et al. (2009). Cycle Inhibiting Factors (CIFs) are a growing family of functional cyclomodulins present in invertebrate and mammal bacterial pathogens. PLoS ONE 4:e4855. doi: 10.1371/journal.pone.0004855

Jubelin, G., Taieb, F., Duda, D. M., Hsu, Y., Samba-Louaka, A., Nobe, R., et al. (2010). Pathogenic bacteria target NEDD8-conjugated cullins to hijack host-cell signaling pathways. PLoS Pathog. 6:e1001128. doi: 10.1371/journal.ppat.1001128

Junaid, M., Linn, A. K., Javadi, M. B., Al-Gubare, S., Ali, N., and Katzenmeier, G. (2016). Vacuolating cytotoxin A (VacA) - A multitalented pore-forming toxin from Helicobacter pylori. Toxicon 118, 27-35. doi: 10.1016/j.toxicon.2016.04.037

Kamanova, J., Kofronova, O., Masin, J., Genth, H., Vojtova, J., Linhartova, I., et al. (2008). Adenylate cyclase toxin subverts phagocyte function by RhoA inhibition and unproductive ruffling. J. Immunol. 181, 5587-5597. doi: 10.4049/jimmunol.181.8.5587

Kassam, A., Der, S. D., and Mogridge, J. (2005). Differentiation of human monocytic cell lines confers susceptibility to Bacillus anthracis lethal toxin. Cell. Microbiol. 7, 281-292. doi: 10.1111/j.1462-5822.2004.00458.x

Khelef, N., and Guiso, N. (1995). Induction of macrophage apoptosis by Bordetella pertussis adenylate cyclase-hemolysin. FEMS Microbiol. Lett. 134, 27-32. doi: 10.1111/j.1574-6968.1995.tb07909.x

Kim, I.-J., and Blanke, S. R. (2012). Remodeling the host environment: modulation of the gastric epithelium by the Helicobacter pylori vacuolating toxin (VacA). Front. Cell. Infect. Microbiol. 2:37. doi: 10.3389/fcimb.2012.00037

Kim, K.-M., Lee, S.-G., Kim, J.-M., Kim, D.-S., Song, J.-Y., Kang, H.-L., et al. (2010). Helicobacter pylori $\gamma$-glutamyltranspeptidase induces cell cycle arrest at the G1-S phase transition. J. Microbiol. 48, 372-377. doi: 10.1007/s12275-0109293-8

Kimura, M., Goto, S., Wada, A., Yahiro, K., Niidome, T., Hatakeyama, T., et al. (1999). Vacuolating cytotoxin purified fromHelicobacter pyloricauses mitochondrial damage in human gastric cells. Microb. Pathog. 26, 45-52. doi: 10.1006/mpat.1998.0241

Knust, Z., Blumenthal, B., Aktories, K., and Schmidt, G. (2009). Cleavage of Escherichia coli cytotoxic necrotizing factor 1 is required for full biologic activity. Infect. Immun. 77, 1835-1841. doi: 10.1128/IAI.01145-08

Knust, Z., and Schmidt, G. (2010). Cytotoxic Necrotizing Factors (CNFs)-a growing toxin family. Toxins 2, 116-127. doi: 10.3390/toxins2010116

Koo, H.-M., VanBrocklin, M., McWilliams, M. J., Leppla, S. H., Duesbery, N. S., and Woude, G. F. V. (2002). Apoptosis and melanogenesis in human 
melanoma cells induced by anthrax lethal factor inactivation of mitogenactivated protein kinase kinase. Proc. Natl. Acad. Sci. U.S.A. 99, 3052-3057. doi: $10.1073 /$ pnas. 052707699

Kouokam, J. C., Wai, S. N., Fallman, M., Dobrindt, U., Hacker, J., and Uhlin, B. E. (2006). Active cytotoxic necrotizing factor 1 associated with outer membrane vesicles from uropathogenic Escherichia coli. Infect. Immun. 74, 2022-2030. doi: 10.1128/IAI.74.4.2022-2030.2006

Krachler, A. M., Woolery, A. R., and Orth, K. (2011). Manipulation of kinase signaling by bacterial pathogens. J. Cell Biol. 195, 1083-1092. doi: $10.1083 /$ jcb.201107132

Kretschmer, D., Gleske, A.-K., Rautenberg, M., Wang, R., Kšberle, M., Bohn, E., et al. (2010). Human Formyl Peptide Receptor 2 (FPR2/ALX) senses highly pathogenic Staphylococcus aureus. Cell Host Microbe 7, 463-473. doi: 10.1016/j.chom.2010.05.012

Lee, M.-S., Koo, S., Jeong, D. G., and Tesh, V. L. (2016). Shiga toxins as multi-functional proteins: induction of host cellular stress responses, role in pathogenesis and therapeutic applications. Toxins 8:E77. doi: $10.3390 /$ toxins 8030077

Lemaitre, B., and Girardin, S. E. (2013). Translation inhibition and metabolic stress pathways in the host response to bacterial pathogens. Nat. Rev. Microbiol. 11, 365-369. doi: 10.1038/nrmicro3029

Lemichez, E., and Aktories, K. (2013). Hijacking of Rho GTPases during bacterial infection. Exp. Cell Res. 319, 2329-2336. doi: 10.1016/j.yexcr.2013. 04.021

Lemonnier, M., Landraud, L., and Lemichez, E. (2007). Rho GTPase-activating bacterial toxins: from bacterial virulence regulation to eukaryotic cell biology. FEMS Microbiol. Rev. 31, 515-534. doi: 10.1111/j.1574-6976.2007.00078.x

Leppla, S. H. (1982). Anthrax toxin edema factor: a bacterial adenylate cyclase that increases cyclic AMP concentrations of eukaryotic cells. Proc. Natl. Acad. Sci. U.S.A. 79, 3162-3166.

Lerm, M., Selzer, J., Hoffmeyer, A., Rapp, U. R., Aktories, K., and Schmidt, G. (1999). Deamidation of Cdc42 and Rac by Escherichia coli cytotoxic necrotizing factor 1: activation of c-Jun N-terminal kinase in HeLa cells. Infect. Immun. 67, 496-503.

Li, Y., Yin, W., Wang, X., Zhu, W., Huang, Y., and Yan, G. (2007). Cholera toxin induces malignant glioma cell differentiation via the PKA/CREB pathway. Proc. Natl. Acad. Sci. U.S.A. 104, 13438-13443. doi: 10.1073/pnas.0701 990104

Lim, K.-H., and Staudt, L. M. (2013). Toll-like receptor signaling. Cold Spring Harb. Perspect. Biol. 5, a011247-a011247. doi: 10.1101/cshperspect.a011247

Lim, S., and Kaldis, P. (2013). Cdks, cyclins and CKIs: roles beyond cell cycle regulation. Development 140, 3079-3093. doi: 10.1242/dev.091744

Liyanage, N. P. M., Manthey, K. C., Dassanayake, R. P., Kuszynski, C. A., Oakley, G. G., and Duhamel, G. E. (2010). Helicobacter hepaticus cytolethal distending toxin causes cell death in intestinal epithelial cells via mitochondrial apoptotic pathway. Helicobacter 15, 98-107. doi: 10.1111/j.1523-5378.2010.00749.x

Majoul, I., Schmidt, T., Pomasanova, M., Boutkevich, E., Kozlov, Y., and Sšling, H.-D. (2002). Differential expression of receptors for Shiga and Cholera toxin is regulated by the cell cycle. J. Cell Sci. 115, 817-826.

Malorni, W., and Fiorentini, C. (2006). Is the Rac GTPase-activating toxin CNF1 a smart hijacker of host cell fate? FASEB J. 20, 606-609. doi: 10.1096/fj.05-4706hyp

Manente, L., Perna, A., Buommino, E., Altucci, L., Lucariello, A., Citro, G., et al. (2008). The Helicobacter pylori's protein VacA has direct effects on the regulation of cell cycle and apoptosis in gastric epithelial cells. J. Cell. Physiol. 214, 582-587. doi: $10.1002 /$ jcp.21242

Márquez, L. B., Velázquez, N., Repetto, H. A., Paton, A. W., Paton, J. C., Ibarra, C., et al. (2014). Effects of Escherichia Coli subtilase cytotoxin and shiga toxin 2 on primary cultures of human renal tubular epithelial cells. PLoS ONE 9:e87022. doi: 10.1371/journal.pone.0087022

Martín, C., Etxaniz, A., Uribe, K. B., Etxebarria, A., González-Bullón, D., Arlucea, J., et al. (2015). Adenylate cyclase toxin promotes bacterial internalisation into non phagocytic cells. Sci. Rep. 5:13774. doi: 10.1038/srep13774

McClure, J.-A., Conly, J. M., Lau, V., Elsayed, S., Louie, T., Hutchins, W., et al. (2006). Novel multiplex PCR assay for detection of the staphylococcal virulence marker panton-valentine leukocidin genes and simultaneous discrimination of methicillin-susceptible from -resistant Staphylococci. J. Clin. Microbiol. 44, 1141-1144. doi: 10.1128/JCM.44.3.1141-1144.2006
McCormack, R. M., Lyapichev, K., Olsson, M. L., Podack, E. R., and Munson, G. P. (2015). Enteric pathogens deploy cell cycle inhibiting factors to block the bactericidal activity of Perforin-2. Elife 4:e06505. doi: 10.7554/eLife.06505

McGovern, K. J., Blanchard, T. G., Gutierrez, J. A., Czinn, S. J., Krakowka, S., and Youngman, P. (2001). $\gamma$-Glutamyltransferase is a Helicobacter pylori virulence factor but is not essential for colonization. Infect. Immun. 69, 4168-4173. doi: 10.1128/IAI.69.6.4168-4173.2001

Mehlin, C., Headley, C. M., and Klebanoff, S. J. (1999). An inflammatory polypeptide complex from Staphylococcus epidermidis: isolation and characterization. J. Exp. Med. 189, 907-918. doi: 10.1084/jem.189. 6.907

Melton-Celsa, A. R. (2014). Shiga Toxin (Stx) classification, structure, and function. Microbiol. Spectr. 2:EHEC-0024-2013. doi: 10.1128/microbiolspec.EHEC-0024-2013

Melvin, J. A., Scheller, E. V., Miller, J. F., and Cotter, P. A. (2014). Bordetella pertussis pathogenesis: current and future challenges. Nat. Rev. Microbiol. 12, 274-288. doi: $10.1038 /$ nrmicro3235

Mendz, G. L., Hazell, S. L., and van Gorkom, L. (1994). Pyruvate metabolism in Helicobacter pylori. Arch. Microbiol. 162, 187-192. doi: 10.1007/BF00314473

Michelacci, V., Tozzoli, R., Caprioli, A., Martín, R., Scheutz, F., Grande, L., et al. (2013). A new pathogenicity island carrying an allelic variant of the Subtilase cytotoxin is common among Shiga toxin producing Escherichia coli of human and ovine origin. Clin. Microbiol. Infect. 19, E149-E156. doi: 10.1111/1469-0691.12122

Moayeri, M., Leppla, S. H., Vrentas, C., Pomerantsev, A. P., and Liu, S. (2015). Anthrax pathogenesis. Annu. Rev. Microbiol. 69, 185-208. doi: 10.1146/annurev-micro-091014-104523

Morikawa, H., Kim, M., Mimuro, H., Punginelli, C., Koyama, T., Nagai, S., et al. (2010). The bacterial effector Cif interferes with SCF ubiquitin ligase function by inhibiting deneddylation of Cullin1. Biochem. Biophys. Res. Commun. 401, 268-274. doi: 10.1016/j.bbrc.2010.09.048

Morinaga, N., Yahiro, K., Matsuura, G., Moss, J., and Noda, M. (2008). Subtilase cytotoxin, produced by Shiga-toxigenic Escherichia coli, transiently inhibits protein synthesis of Vero cells via degradation of $\mathrm{BiP}$ and induces cell cycle arrest at G1 by downregulation of cyclin D1. Cell. Microbiol. 10, 921-929. doi: 10.1111/j.1462-5822.2007.01094.x

Mve-Obiang, A., Lee, R. E., Portaels, F., and Small, P. L. C. (2003). Heterogeneity of mycolactones produced by clinical isolates of Mycobacterium ulcerans: implications for virulence. Infect. Immun. 71, 774-783. doi: 10.1128/IAI.71.2.774-783.2003

Nalepa, G., Barnholtz-Sloan, J., Enzor, R., Dey, D., He, Y., Gehlhausen, J. R., et al. (2013). The tumor suppressor CDKN3 controls mitosis. J. Cell Biol. 201, 997-1012. doi: 10.1083/jcb.201205125

Nath, S., Ghatak, D., Das, P., and Roychoudhury, S. (2015). Transcriptional control of mitosis: deregulation and cancer. Cancer Endocrinol. 6:60. doi: $10.3389 /$ fendo.2015.00060

Nesić, D., Hsu, Y., and Stebbins, C. E. (2004). Assembly and function of a bacterial genotoxin. Nature 429, 429-433. doi: 10.1038/nature02532

New, D. C., and Wong, Y. H. (2007). Molecular mechanisms mediating the G protein-coupled receptor regulation of cell cycle progression. J. Mol. Signal. 2:2. doi: 10.1186/1750-2187-2-2

Nichols, J. M., Maiellaro, I., Abi-Jaoude, J., Curci, S., and Hofer, A. M. (2015). "Store-operated" cAMP signaling contributes to $\mathrm{Ca}^{2+}$-activated $\mathrm{Cl}-$ secretion in T84 colonic cells. Am. J. Physiol. Gastrointest. Liver Physiol. 309, G670-G679. doi: 10.1152/ajpgi.00214.2015

Nougayrede, J.-P., Boury, M., Tasca, C., Marches, O., Milon, A., Oswald, E., et al. (2001). Type III secretion-dependent cell cycle block caused in HeLa cells by enteropathogenic Escherichia coli O103. Infect. Immun. 69, 6785-6795. doi: 10.1128/IAI.69.11.6785-6795.2001

Nougayrede, J.-P., Taieb, F., Rycke, J. D., and Oswald, E. (2005). Cyclomodulins: bacterial effectors that modulate the eukaryotic cell cycle. Trends Microbiol. 13, 103-110. doi: 10.1016/j.tim.2005.01.002

Nours, J. L., Paton, A. W., Byres, E., Troy, S., Herdman, B. P., Johnson, M. D., et al. (2013). Structural basis of subtilase cytotoxin SubAB assembly. J. Biol. Chem. 288, 27505-27516. doi: 10.1074/jbc.M113.462622

Novick, R. P. (2003). Autoinduction and signal transduction in the regulation of staphylococcal virulence. Mol. Microbiol. 48, 1429-1449. doi: $10.1046 / j .1365-2958.2003 .03526 . x$ 
Odumosu, O., Nicholas, D., Yano, H., and Langridge, W. (2010). AB toxins: a paradigm switch from deadly to desirable. Toxins 2, 1612-1645. doi: $10.3390 /$ toxins 2071612

Orth, K., Palmer, L. E., Bao, Z. Q., Stewart, S., Rudolph, A. E., Bliska, J. B., et al. (1999). Inhibition of the mitogen-activated protein kinase kinase superfamily by a Yersinia effector. Science 285, 1920-1923

Oswald, E., Nougayrède, J.-P., Taieb, F., and Sugai, M. (2005). Bacterial toxins that modulate host cell-cycle progression. Curr. Opin. Microbiol. 8, 83-91. doi: 10.1016/j.mib.2004.12.011

Otto, M. (2012). MRSA virulence and spread. Cell. Microbiol. 14, 1513-1521. doi: $10.1111 / \mathrm{j} .1462-5822.2012 .01832 . \mathrm{x}$

Otto, M. (2014). Phenol-soluble modulins. Int. J. Med. Microbiol. 304, 164-169. doi: 10.1016/j.ijmm.2013.11.019

Palframan, S. L., Kwok, T., and Gabriel, K. (2012). Vacuolating cytotoxin A (VacA), a key toxin for Helicobacter pylori pathogenesis. Front. Cell. Infect. Microbiol. 2:92. doi: $10.3389 /$ fcimb.2012.00092

Paton, A. W., and Paton, J. C. (2010). Escherichia coli subtilase cytotoxin. Toxins 2, 215-228. doi: 10.3390/toxins2020215

Paton, A. W., Srimanote, P., Talbot, U. M., Wang, H., and Paton, J. C. (2004). A new family of potent AB5 cytotoxins produced by Shiga toxigenic Escherichia coli. J. Exp. Med. 200, 35-46. doi: 10.1084/jem.20040392

Paton, J. C., and Paton, A. W. (1998). Pathogenesis and Diagnosis of Shiga Toxin-Producing Escherichia coli Infections. Clin. Microbiol. Rev. 11, 450-479.

Periasamy, S., Joo, H.-S., Duong, A. C., Bach, T.-H. L., Tan, V. Y., Chatterjee, S. S., et al. (2012). How Staphylococcus aureus biofilms develop their characteristic structure. Proc. Natl. Acad. Sci. U.S.A. 109, 1281-1286. doi: 10.1073/pnas.1115006109

Peschel, A., and Otto, M. (2013). Phenol-soluble modulins and staphylococcal infection. Nat. Rev. Microbiol. 11, 667-673. doi: 10.1038/nrmicro3110

Phillips, R., Sarfo, F. S., Guenin-Macé, L., Decalf, J., Wansbrough-Jones, M., Albert, M. L., et al. (2009). Immunosuppressive signature of cutaneous Mycobacterium ulcerans infection in the peripheral blood of patients with buruli ulcer disease. J. Infect. Dis. 200, 1675-1684. doi: 10.1086/646615

Ricci, V., Giannouli, M., Romano, M., and Zarrilli, R. (2014). Helicobacter pylori gamma-glutamyl transpeptidase and its pathogenic role. World J. Gastroenterol. 20, 630-638. doi: 10.3748/wjg.v20.i3.630

Rolando, M., Stefani, C., Flatau, G., Auberger, P., Mettouchi, A., Mhlanga, M., et al. (2010). Transcriptome dysregulation by anthrax lethal toxin plays a key role in induction of human endothelial cell cytotoxicity. Cell. Microbiol. 12, 891-905. doi: 10.1111/j.1462-5822.2010.01438.x

Rosadi, F., Fiorentini, C., and Fabbri, A. (2016). Bacterial protein toxins in human cancers. Pathog. Dis. 74:ftv105. doi: 10.1093/femspd/ftv105

Rossi Paccani, S., and Baldari, C. T. (2011). T cell targeting by anthrax toxins: two faces of the same coin. Toxins 3, 660-671. doi: 10.3390/toxins 3060660

Samba-Louaka, A., Nougayrède, J.-P., Watrin, C., Jubelin, G., Oswald, E., and Taieb, F. (2008). Bacterial cyclomodulin Cif blocks the host cell cycle by stabilizing the cyclin-dependent kinase inhibitors $\mathrm{p} 21^{\text {waf1 }}$ and $\mathrm{p} 27^{\mathrm{kip} 1}$. Cell. Microbiol. 10, 2496-2508. doi: 10.1111/j.1462-5822.2008.01224.x

Samba-Louaka, A., Nougayrède, J.-P., Watrin, C., Oswald, E., and Taieb, F. (2009a). The enteropathogenic Escherichia coli effector Cif induces delayed apoptosis in epithelial cells. Infect. Immun. 77, 5471-5477. doi: 10.1128/IAI.00860-09

Samba-Louaka, A., Taieb, F., Nougayrède, J.-P., and Oswald, E. (2009b). Cif type III effector protein: a smart hijacker of the host cell cycle. Future Microbiol. 4, 867-877. doi: 10.2217/fmb.09.60

Sanchez, I., and Dynlacht, B. (2005). New insights into cyclins, CDKs, and cell cycle control. Semin. Cell Dev. Biol. 16, 311-321. doi: 10.1016/j.semcdb.2005.02.007

Sánchez, J., and Holmgren, J. (2011). Cholera toxin foe \& a friend. Indian J. Med. Res. 133, 153-163.

Sandvig, K., Bergan, J., Dyve, A.-B., Skotland, T., and Torgersen, M. L. (2010). Endocytosis and retrograde transport of Shiga toxin. Toxicon 56, 1181-1185. doi: 10.1016/j.toxicon.2009.11.021

Sarfo, F. S., Phillips, R., Wansbrough-Jones, M., and Simmonds, R. E. (2016). Recent advances: role of mycolactone in the pathogenesis and monitoring of Mycobacterium ulcerans infection/Buruli ulcer disease. Cell. Microbiol. 18, 17-29. doi: 10.1111/cmi.12547

Schmees, C., Prinz, C., Treptau, T., Rad, R., Hengst, L., Voland, P., et al. (2007). Inhibition of T-cell proliferation by Helicobacter pylori $\gamma$-glutamyl transpeptidase. Gastroenterology 132, 1820-1833. doi: 10.1053/j.gastro.2007.02.031

Schmidt, G., Sehr, P., Wilm, M., Selzer, J., Mann, M., and Aktories, K. (1997). Gln 63 of Rho is deamidated by Escherichia coli cytotoxic necrotizing factor-1. Nature 387, 725-729. doi: 10.1038/42735

Scobie, H. M., Rainey, G. J. A., Bradley, K. A., and Young, J. A. T. (2003). Human capillary morphogenesis protein 2 functions as an anthrax toxin receptor. Proc. Natl. Acad. Sci. U.S.A. 100, 5170-5174. doi: 10.1073/pnas.0431098100

Scuron, M. D., Boesze-Battaglia, K., Dlakić, M., and Shenker, B. J. (2016). The cytolethal distending toxin contributes to microbial virulence and disease pathogenesis by acting as a tri-perditious toxin. Front. Cell. Infect. Microbiol. 6:168. doi: 10.3389/fcimb.2016.00168

Shenker, B. J., Dlakić, M., Walker, L. P., Besack, D., Jaffe, E., LaBelle, E., et al. (2007). A novel mode of action for a microbial-derived immunotoxin: the cytolethal distending toxin subunit B exhibits phosphatidylinositol 3,4,5-triphosphate phosphatase activity. J. Immunol. 178, 5099-5108. doi: 10.4049/jimmunol.178.8.5099

Shibayama, K., Kamachi, K., Nagata, N., Yagi, T., Nada, T., Doi, Y., et al. (2003). A novel apoptosis-inducing protein from Helicobacter pylori. Mol. Microbiol. 47, 443-451. doi: 10.1046/j.1365-2958.2003.03305.x

Simmonds, R. E., Lali, F. V., Smallie, T., Small, P. L. C., and Foxwell, B. M. (2009). Mycolactone inhibits monocyte cytokine production by a posttranscriptional mechanism. J. Immunol. 182, 2194-2202. doi: 10.4049/jimmunol.0802294

Song, J., Gao, X., and Galán, J. E. (2013). Structure and function of the Salmonella Typhi chimaeric A2B5 typhoid toxin. Nature 499, 350-354. doi: $10.1038 /$ nature 12377

Spaan, A. N., Henry, T., van Rooijen, W. J. M., Perret, M., Badiou, C., Aerts, P. C., et al. (2013). The Staphylococcal toxin panton-valentine leukocidin targets human C5a receptors. Cell Host Microbe 13, 584-594. doi: 10.1016/j.chom.2013.04.006

Spanó, S., Ugalde, J. E., and Galán, J. E. (2008). Delivery of a salmonella typhi exotoxin from a host intracellular compartment. Cell Host Microbe 3, 30-38. doi: 10.1016/j.chom.2007.11.001

Taieb, F., Nougayrède, J.-P., and Oswald, E. (2011). Cycle Inhibiting Factors (Cifs): cyclomodulins that usurp the ubiquitin-dependent degradation pathway of host cells. Toxins 3, 356-368. doi: 10.3390/toxins3040356

Taieb, F., Nougayrède, J.-P., Watrin, C., Samba-Louaka, A., and Oswald, E. (2006). Escherichia coli cyclomodulin Cif induces $G_{2}$ arrest of the host cell cycle without activation of the DNA-damage checkpoint-signalling pathway. Cell. Microbiol. 8, 1910-1921. doi: 10.1111/j.1462-5822.2006. 00757.x

Taieb, F., Petit, C., Nougayrède, J.-P., and Oswald, E. (2016). The enterobacterial genotoxins: cytolethal distending toxin and colibactin. EcoSal Plus 7, 1-21. doi: 10.1128/ecosalplus.ESP-0008-2016

Taieb, F., Sváb, D., Watrin, C., Oswald, E., and Tóth, I. (2015). Cytolethal distending toxin $\mathrm{A}, \mathrm{B}$ and $\mathrm{C}$ subunit proteins are necessary for the genotoxic effect of Escherichia coli CDT-V. Acta Vet. Hung. 63, 1-10. doi: 10.1556/AVet.2015.001

Tang, W.-J., and Guo, Q. (2009). The adenylyl cyclase activity of anthrax edema factor. Mol. Aspects Med. 30, 423-430. doi: 10.1016/j.mam.2009.06.001

Thrasher, A. J., and Burns, S. O. (2010). WASP: a key immunological multitasker. Nat. Rev. Immunol. 10, 182-192. doi: 10.1038/nri2724

Vermeulen, K., Van Bockstaele, D. R., and Berneman, Z. N. (2003). The cell cycle: a review of regulation, deregulation and therapeutic targets in cancer. Cell Prolif. 36, 131-149. doi: 10.1046/j.1365-2184.2003.00266.x

Vojtova, J., Kamanova, J., and Sebo, P. (2006). Bordetella adenylate cyclase toxin: a swift saboteur of host defense. Curr. Opin. Microbiol. 9, 69-75. doi: 10.1016/j.mib.2005.12.011

Wang, C., and Youle, R. J. (2009). The role of mitochondria in apoptosis. Annu. Rev. Genet. 43, 95-118. doi: 10.1146/annurev-genet-102108-134850

Wang, H., Paton, A. W., McColl, S. R., and Paton, J. C. (2011). In vivo leukocyte changes induced by Escherichia coli subtilase cytotoxin. Infect. Immun. 79, 1671-1679. doi: 10.1128/IAI.01204-10

Wang, H.-R., Zhang, Y., Ozdamar, B., Ogunjimi, A. A., Alexandrova, E., Thomsen, G. H., et al. (2003). Regulation of cell polarity and protrusion formation by targeting RhoA for degradation. Science 302, 1775-1779. doi: $10.1126 /$ science. 1090772 
Wang, R., Braughton, K. R., Kretschmer, D., Bach, T.-H. L., Queck, S. Y., Li, M., et al. (2007). Identification of novel cytolytic peptides as key virulence determinants for community-associated MRSA. Nat. Med. 13, 1510-1514. doi: $10.1038 / \mathrm{nm} 1656$

Williams, K., Cullati, S., Sand, A., Biterova, E. I., and Barycki, J. J. (2009). Crystal structure of acivicin-inhibited $\gamma$-glutamyltranspeptidase reveals critical roles for its C-terminus in autoprocessing and catalysis. Biochemistry 48, 2459-2467. doi: $10.1021 /$ bi8014955

Yahiro, K., Tsutsuki, H., Ogura, K., Nagasawa, S., Moss, J., and Noda, M. (2012). Regulation of Subtilase cytotoxin (SubAB)-induced cell death by a PKRlike endoplasmic reticulum kinase (PERK)-dependent proteasome pathway in HeLa cells. Infect. Immun. 80, 1803-1814. doi: 10.1128/IAI.06164-11

Yahiro, K., Tsutsuki, H., Ogura, K., Nagasawa, S., Moss, J., and Noda, M. (2014). DAP1, a negative regulator of autophagy, controls SubAB-mediated apoptosis and autophagy. Infect. Immun. 82, 4899-4908. doi: 10.1128/IAI. 02213-14

Zheng, X., Ou, Y., Shu, M., Wang, Y., Zhou, Y., Su, X., et al. (2014). Cholera toxin, a typical protein kinase A activator, induces G1 phase growth arrest in human bladder transitional cell carcinoma cells via inhibiting the c-Raf/MEK/ERK signaling pathway. Mol. Med. Rep. 9, 1773-1779. doi: 10.3892/mmr.2014.2054
Zhou, B.-B. S., and Elledge, S. J. (2000). The DNA damage response: putting checkpoints in perspective. Nature 408, 433-439. doi: 10.1038/35044005

Zhou, Y., and Zhu, Y. (2015). Diversity of bacterial manipulation of the host ubiquitin pathways. Cell. Microbiol. 17, 26-34. doi: 10.1111/cmi.12384

Conflict of Interest Statement: The authors declare that the research was conducted in the absence of any commercial or financial relationships that could be construed as a potential conflict of interest.

The reviewer TF and handling Editor declared their shared affiliation, and the handling Editor states that the process nevertheless met the standards of a fair and objective review.

Copyright $\odot 2017$ El-Aouar Filho, Nicolas, De Paula Castro, Deplanche, De Carvalho Azevedo, Goossens, Taieb, Lina, Le Loir and Berkova. This is an open-access article distributed under the terms of the Creative Commons Attribution License (CC BY). The use, distribution or reproduction in other forums is permitted, provided the original author(s) or licensor are credited and that the original publication in this journal is cited, in accordance with accepted academic practice. No use, distribution or reproduction is permitted which does not comply with these terms. 